Manufacturing capability and organizational performance: The role of entrepreneurial orientation

\author{
Roberto Chavez \\ Facultad de Economía y Empresa \\ Universidad Diego Portales \\ Avda. Santa Clara 797 \\ Huechuraba, Santiago, Chile \\ Email: roberto.chavez@udp.cl \\ Tel: +56 222130131
}

\author{
Wantao Yu \\ Kent Business School \\ University of Kent \\ Sail \& Colour Loft, The Historic Dockyard, Chatham \\ Kent, ME4 4TE \\ Email: W.Yu@kent.ac.uk \\ Tel.: +441634888486
}

Mark A. Jacobs

Department of Operations Management, College of Business

University of Dayton, 300 College Park

Dayton, $\mathrm{OH} 45469$, United States

Email: majacobs@udayton.edu

Tel: +1 9372292204

Mengying Feng

School of Management

Chongqing Jiaotong University

Xufu Dadao, Nanan District

Chongqing, China

Email: fengmengying@cqjtu.edu.cn

Tel.: +862386079717 


\title{
Manufacturing capability and organizational performance: The role of entrepreneurial orientation
}

\begin{abstract}
To date there have been mixed findings about the impact of various manufacturing capabilities on organizational performance. This study investigates entrepreneurial orientation (EO) from the perspective of the Contingency Theory as a potential explanatory variable. The findings are that EO moderates the relationship between capabilities in flexibility and cost and organizational performance. Further, without a sufficient level of EO, there are no benefits to organizational performance and as such EO is positioned as a strategic resource to cultivate and nurture. This study provides insight into the connection between operational capabilities and firm level strategy. Specifically, it appears that EO may be the mechanism whereby manufacturing capabilities are linked to market needs.
\end{abstract}

\section{Introduction}

Since the publication of "Manufacturing - Missing Link in Corporate Strategy" (Skinner, 1969), manufacturing capability has gained recognition as a source of competitive advantage (Wheelright, 1984). Manufacturing capability refers to the manufacturer's actual competitive strength relative to primary competitors (Rosenzweig et al., 2003, Swink et al., 2007), which should be aligned with the strategic goals of the organization (Ho et al., 2002). There is general agreement in the operations management $(\mathrm{OM})$ literature that quality, delivery, flexibility and cost are the core manufacturing capability dimensions (White, 1996; Narasimhan and Jayaram, 1998; Li, 2000) that have been linked to organizational performance (Peng et al, 2008; Terjesen et al., 2011). Organizational performance refers to how well an organization achieves its market and financial goals (Li et al., 2005). Herein we have adopted the resource-based view (RBV) to explain the association between manufacturing capabilities and organizational performance. The RBV suggests that competitive advantage can be obtained and sustained over time from the internal organization and exploitation of resources such as manufacturing capabilities (Peng et al., 2008; Terjesen et al., 2011). 
Several empirical studies have found support for the positive association between manufacturing capabilities and organizational performance (e.g. Li, 2000; Fawcett et al., 2000; Tracey, 2005; Yu et al., 2014); however, results are mixed (e.g. Lau Antonio et al., 2007; Rosenzweig et al., 2003; Swink et al., 2007). While the inconsistency in the results may be explained by implementation difficulties in moving organizations towards excellence, it may alternatively be explained by contingency theory (CT) (Sousa and Voss, 2008), which suggests that organizations are not closed systems, in that they are exposed to organizational/environmental factors that affect resource munificence and performance (Schoonhoven, 1981; Wong et al., 2011). Complementing the internal focus of the RBV (Miller and Shamsie, 1996), the current study adopts CT. While the contingency view is not new in the OM literature, empirical studies embracing this perspective are more rare (Sousa and Voss, 2008). Specifically, it has been suggested that special attention be given to executing studies that examine contingencies in the context of multiple dimensions of operational capability (Sousa and Voss, 2008). Accordingly, this research extends the traditional manufacturing capability-performance model by investigating financial performance contingent upon the level of entrepreneurial orientation.

Cross-disciplinary research in OM can be a fruitful approach for theory building and practice (Whetten, 1989). This should certainly be true at the intersection of OM and entrepreneurship (Singhal and Singhal, 2012). Specifically, entrepreneurial orientation (EO) has attracted a large stream of research and has become a central construct in the entrepreneurship literature (Rauch et al., 2009). EO refers to the processes and methods used to act entrepreneurially, e.g. innovative posture, proactiveness, and risk-taking behaviour (Kreiser and Davis, 2012; Rauch et al., 2009). There are a number of explicit connection and opportunities for OM and EO (Kickul et al., 2011; Krishnan, 2013; Phan and Chambers, 2013). Entrepreneurial behaviour is acutely important in that it allows firms to leverage their manufacturing competencies and develop capabilities such as flexibility, agility, quality and efficiency (Handfield et al., 2009; Hsu et al., 2011). Entrepreneurial traits such as tolerance to risk, innovativeness and proactiveness allow firms to respond to market opportunities by developing manufacturing capabilities to meet rapidly changing needs (Giunipero et al., 2005). Despite this argument, the application of EO in the OM domain is in a nascent stage (Giunipero et al., 2005), and 
there is a dearth of empirical work studying EO's impact on the manufacturing capability-performance links described above.

There have been studies investigating the manufacturing capability-performance link and the role of external characteristics of the environment such as the rate of innovation in industries (e.g., Nadkarni and Narayanan, 2007), environmental dynamism (e.g., Terjesen et al., 2011) and technological turbulence (e.g., Chavez et al., 2015a). It has been argued that organizations respond directly to external environments, e.g. those characterized by innovativeness, dynamism, and high technology, by being entrepreneurial (i.e., being innovative, exhibiting proactive behaviour, and taking risks) (Covin and Slevin, 1991; Khandwalla, 1987). However, these external environmental characteristics may not reflect faithfully the nature of EO. As such, this points to the need for further research addressing the role of EO in the manufacturing capabilityperformance link. The research herein illuminates the intersection between $\mathrm{OM}$ and entrepreneurship by specifically exploring the relationship of EO to the manufacturing capability-organizational performance link.

Thus this research adds to the body of knowledge on OM and entrepreneurship by addressing two research questions: 1) To what extent does manufacturing capability impact organizational performance, and 2) To what extent does EO affect the manufacturing capability and organizational performance relationship. By investigating the relationship between multiple manufacturing capability dimensions and organizational performance this study will explain inconsistencies in the literature. By exploring the intersection between OM and entrepreneurship this study represents crossdisciplinary research between OM and entrepreneurship, which could lead potentially to new insight and tangible benefits for both theory and practice. In particular, by considering the role of EO in the manufacturing capability-organizational performance link, this study will explain how certain manufacturing capabilities could be built and strengthen through entrepreneurial behaviour. Finally, this study contributes to the building of the RBV and CT to explain OM and entrepreneurship phenomena.

\section{Theoretical background and hypotheses development}

\subsection{Resource-based view and contingency theory}


Two theoretical approaches serve as the bases for an enhanced understanding of the relationship between manufacturing capabilities, organizational performance and EO. These theories represent complementary rather that competing views. The first theory is the RBV and the second is CT.

The RBV suggests that competitive advantage of a firm can be obtained and sustained over time from the internal organization of its resources (Eisenhardt and Martin, 2000). Resources in this context refer to anything that might be thought as strength (or weakness) to the firm such as assets, patents, brand names, capabilities, processes, attributes, distribution locations, information and knowledge (Wernerfelt and Karnani, 1987; Miller and Shamsie, 1996). The RBV adopts an internal view, which focuses on the firm as the primary unit of analysis, and competitive advantage as a result of tangible and intangible resources, which are difficult to create, buy, substitute or imitate (Lavie, 2006). In order to complement its internal view, it has been suggested that the RBV should consider the type of environment in which different resources can be more appropriate for performance improvement (Miller and Shamsie, 1996). According to Porter (1991), the competitive value of resources can be enhanced (or eliminated) by changes in elements of environment (e.g., technology, competition, customer behaviour). In line with this argument, CT is based on the premise that no universal set of strategic choices applies to every business situation (Fredericks, 2005), which argues against a singular approach suggesting there is no 'one-size-fits-all' way to organize a company's strategy (Ginsberg and Venkatraman, 1985). Early proponents such as Lawrence and Lorsch (1967) suggested that the environment plays a key role in shaping an organization's strategy, and that one single organizational model will simply not achieve optimal results. Furthermore, Hofer (1975) and Schoonhoven (1981) pointed out that, as well as improving the choice of the strategy made by the organization, CT should, at the very least, help to improve performance and productivity in corporations. This implies that the contingency framework should not only incorporate organizational and environmental factors but also performance (Ginsberg and Venkatraman, 1985; Sousa and Voss, 2008). Accordingly, drawing from the logic expressed in the RBV we present a conceptual framework that studies the effect of manufacturing capability on organizational performance. We then add that the manufacturing capabilityorganizational performance link (see Figure 1) can be contingent upon characteristics of the environment (i.e. EO). 


\subsection{Manufacturing capabilities and organizational performance}

Manufacturing capabilities have been posited as important contributors to organizational performance (Peng et al., 2008; Terjesen et al., 2011). Manufacturing capabilities are developed internally and are difficult to imitate and transfer (Swink and Hegarty, 2008), which makes them 'valuable' and 'inimitable' in the context of the RBV framework (Wernerfelt and Karnani, 1987). The notion of manufacturing capabilities was first introduced by Hayes and Wheelwright (1984) as the dimensions along which companies choose to compete (Krause et al., 2001, Narasimhan and Das 2001). These capabilities are associated with a set of supportive decisions and practices regarding the structure and/or infrastructure of operations (Wheelright, 1984). The result is that manufacturing capability has been typically conceptualized as an operational strength manifested in competitive performance (Peng et al., 2008). However, manufacturing capability refers to both process abilities as well as operational outcomes, which has brought some semantic differences and confusion over the term in the literature (Swink and Hegarty, 1998; Ward et al., 1998; Lau Antonio et al., 2007; Swink et al., 2007; Peng et al., 2008). The present study conceptualizes manufacturing capability as the actual (or realized) competitive ability (or strength) relative to primary competitors in the targeted market (Swink and Hegarty, 1998; Ho et al., 2002; Rosenzweig et al., 2003; Swink et al., 2007). For example, cost capability refers to a company's actual ability to produce products at a lower cost than its competitors thus facilitating the execution of a price based strategy profitably. There is broad agreement in the OM literature that manufacturing capability is manifested in four dimensions: quality, delivery, flexibility and cost (Ward et al., 1994; Ward et al., 1998; Narasimhan and Jayaram 1998; Krause et al., 2001; Rosenzweig et al., 2003; Swink et al., 2005; Jacobs et al., 2007; Swink et al., 2007).

From the literature review, it is clear that studies have used a combination of manufacturing capability dimensions (e.g. Chavez et al., 2015b; Swink et al., 2005; Swink et al., 2007). This can be the result of a general trend where manufacturers combine manufacturing capabilities simultaneously (Sanders, 2007). The main rationale is that, in current intense competitive times, it is necessary to excel through multiple 
manufacturing capabilities instead of focusing on separate ones (Boyer and Lewis, 2002). This is more evident in underdeveloped countries that have not yet achieved the performance frontier (Boon-itt and Wong, 2016) such as the case of China in the present study. Considering the above argument, the present study focuses on testing multiple manufacturing capability dimensions, namely quality, delivery, flexibility and cost.

While Quality is a multidimensional construct, operations management based studies have generally focused on the conformance dimension, which is described as the degree to which products meet manufacturing specifications (Lau Antonio et al., 2007; Slack et al., 2009). However, it has also been argued that there are other important aspects of quality that go beyond product specification, which refer to the degree to which the product is fit for use; the degree to which it contains the functionality, features, and styling required by customers (Lau Antonio et al., 2007). Aspects of quality such as good after-sale service or technical support can have an important effect on the number of units sold, and thus quality is an important aspect of sales and profitability (Tracey et al., 1999; Lau Antonio, et al., 2007). Indeed it has been found empirically that quality positively affects and organization's financial performance (Curkovic et al., 2000; Swink et al., 2007) and customer satisfaction (Swink et al., 2007).

Delivery is a timed-based performance construct conceptualized as the ability to deliver products at the specified time (Ward et al. 1998). Delivery performance is often pursued through process enhancements directed at reducing cycle time (Holweg and Pil, 2005) such as setup time reductions or reduction in work in process inventory. A fundamental objective is to minimize lead time so as to effectively meet customer requirements reliably (Jacobs et al., 2011). Another approach is to increase integration with trading partners (Flynn et al., 2010). The premise, which is empirically supported, is that information exchange facilitates timely adjustments to production that facilitate meeting customer needs (Chang, 2009). Delivery incorporates both the dimensions of dependability and speed (Chan, 2003; Lau Antonio et al. 2007; Droge et al., 2012). Dependability refers to doing things on time and the ability to deliver orders correctly on promised due dates (Lau Antonio et al., 2007, Slack et al., 2009). Speed is the ability to deliver goods and/or services faster than competitors, which can be important to winning orders (Ward et al., 1998). With regard to delivery, it has been empirically found that delivery speed and dependability positively influence financial performance 
and customer satisfaction (Rosenzweig et al., 2003; Lau Antonio et al., 2007; Swink et al., 2007).

Flexibility is another important capability, which can lead to competitive advantage (Worren et al., 2002). Worren et al. consider flexibility facilitated by product modularity to be a resource in the sense of the RBV of strategy; i.e. modular designs and the ensuing flexibility may not be easily imitated. Flexibility is described as the ability to adapt and respond to changes in production volume or mix to give customers individual treatment or to introduce new products/services (Chan, 2003; Slack et al., 2009). The literature discusses various types of flexibility such as production mix, volume, modification, and changeover flexibility (Gerwin, 1993; Schmenner and Tatikonda, 2005; Santos Bernardes and Hanna, 2008). A 'flexibility' capability thus implies a firm can respond to special requirements and product innovation to achieve a variety of production outcomes (Gerwin, 1993; Chan, 2003; Schmenner and Tatikonda, 2005). However, flexibility goes beyond the accommodation of product changes and includes the ability to respond to disruptions such as machine breakdowns or late arrival of materials (Chan, 2003; Chavez et al., 2015b). According to Ward et al., (1998), flexibility can be measured by considering aspects such as the ability to accommodate changes to product mix and production volume along with product and process modifications. Studies have supported the significant and positive effect of flexibility on financial and market based performance indicators (Tracey, 2005; Lau Antonio et al., 2007; Jacobs et al., 2011).

Cost is defined as "doing things cheaply, producing goods and services at a cost that enables them to be priced appropriately for the market while still allowing a return to the organization" (Slack et al., 2009, p. 40). Cost efficiency promotes profitability and builds market share through the manufacturer's ability to adjust prices dynamically in response to its market and competition (Swink et al., 2005). It has been claimed that all manufacturers are concerned to some extent with cost (Ward et al., 1998) as cost may be the most significant manufacturing capability since other capabilities influence it. However, considering cost as a sole manufacturing capability may undermine other capabilities (Beamon, 1999; Chan, 2003). With regard to cost, it has been established that cost capabilities drive an organization's financial performance (Fawcett et al., 2000; Rosenzweig et al., 2003; Swink et al., 2005). 
Hence consistent with the RBV, manufacturing capabilities have been posited and found to influence organizational performance (White, 1996; Ward et al., 1998; Flynn et al., 1999; Rosenzweig et al., 2003; Swink et al., 2005; Kim, 2006; Yu et al., 2014); specifically, how well an organization achieves its market and financial goals (Li et al., 2005). Market performance focusing on customer-oriented indicators such as growth in market share (Rosenzweig et al., 2003; Li et al., 2005; Swink et al., 2007) and financial performance referring to indicators that are assumed to reflect the fulfilment of the economic goal of the company such as profitability, return on investments (ROI), return on assets (ROA) and return on sales (ROS) (De Toni and Tonchia, 2001; Chen and Paulraj, 2004).

A considerable number of studies have empirically linked manufacturing capabilities to organizational performance (e.g. Curkovic et al., 2000; Fawcett et al., 2000; Rosenzweig et al., 2003; Swink et al., 2005; Tracey, 2005; Jacobs et al., 2007; Lau Antonio et al., 2007; Swink et al., 2007). In fact, it has even been indicated that is now conventional wisdom that superior manufacturing capabilities in dimensions of quality, delivery, flexibility, and cost enhance organizational performance as measured by market and financial performance (Rosenzweig et al., 2003). Accordingly, it is hypothesized that:

H1: Manufacturing capabilities are positively associated with organizational performance

- H1a: Quality is positively associated with organizational performance

- H1b: Delivery is positively associated with organizational performance

- H1c: Flexibility is positively associated with organizational performance

- H1d: Cost is positively associated with organizational performance

While H1 is not 'interesting' from Whetten's (1989) perspective, it is essential for testing the proposed model and provides a point of replication. Replication entails either an exact duplication or further refinement and extension, for example to other contexts, to increase the certainty of a result (Kerlinger, 1986; Wiengarten et al., 2013). Retesting theory is an important part of the theory development process, which according to Melnyk and Handfield (1998) is an underdeveloped practice in OM research. 


\subsection{Manufacturing capabilities, organizational performance and entrepreneurial orientation}

While several studies have found support for the positive association between manufacturing capabilities and organizational performance, there are others that fail to find support (e.g. Lau Antonio et al., 2007; Rosenzweig et al., 2003; Swink et al., 2005; Swink et al., 2007). For instance, Lau Antonio et al. (2007) report that while delivery and flexibility are positively associated with organizational performance, i.e. sales, profitability, and customer satisfaction, no significant association was found for the effect of low cost and product quality on organizational performance. Fiegenbaum and Karnani (1991) and Swink et al. (2005) could not find support for the association between process flexibility and financial performance. Rosenzweig et al. (2003) found no significant association between cost and customer satisfaction, and delivery reliability and process flexibility led to negative financial performance. Further, Swink et al. (2007) found that flexibility was negatively associated with customer satisfaction, and that cost efficiency was marginally significant but negatively associated with financial performance.

Given the foregoing, it is evident that there are inconsistencies in the results of studies that investigate the relationship between manufacturing capabilities and organizational financial and market performance. While this inconsistency may be the result of the implementation difficulties of moving an organization towards excellence or "worldclass" status, it is more likely explained by contingency theory (CT) (Sousa and Voss, 2008). CT suggests that organizations are not closed systems but rather are exposed to organizational and environmental factors affecting performance (Hofer, 1975; Schoonhoven, 1981; Wong et al., 2011). CT is not new in the management literature (Skinner, 1969); however, theory construction and testing using this approach is relatively recent (Sousa and Voss, 2008). Sousa and Voss explain that special attention should be given to testing contingency models of operational performance since such models have not been studied in sufficient depth. Specifically, the literature could benefit from studies that examine contingency models incorporating multiple dimensions of manufacturing capability (Sousa and Voss, 2008). By way of example Swink et al. (2007) suggested that certain manufacturing capability dimensions might 
be more impactful to organizational performance in certain narrowly defined environments. Further, using multiple (rather than aggregated) measures of manufacturing capability will increase precision (Ketokivi and Schroeder, 2004; Wong et al., 2011). Considering the above argument, CT provides a framework for conceptualizing and structuring the research question in this section. In doing so, the traditional manufacturing capability-organizational performance model described earlier is expanded to include the contingency view and multiple manufacturing capability dimensions.

Thus far, environment has been presented in CT research as a single dimension. However, the CT literature bifurcated the environment as internal and external and presents it as a more structured and disaggregated concept (Lawrence and Lorsch, 1967). Similarly, the OM literature categorizes the environment into contextual characteristics and internal characteristics. Contextual characteristics refer to aspects such as level of uncertainty, manufacturing pressure, and regulatory environment. Internal characteristics describe the company's strategic orientation, organizational infrastructure and culture (Spina and Verganti, 2002; Sousa and Voss, 2008). The present study focuses on the internal characteristics of the environment, and proposes entrepreneurial orientation (EO) as a potential contingency variable for the capabilityperformance relationship.

It has been suggested that cross-disciplinary research can be a fruitful approach leading to new insight and tangible benefits for theory and practice (Walter et al., 2006; Kickul et al., 2011; Song et al., 2011; Singhal and Singhal, 2012). Specifically, there has been increasing interest in the intersection between $\mathrm{OM}$ and entrepreneurship due to the implicit connection between both fields, e.g. process intensiveness, the ability to innovate, the deployment of strategies across and within organizations, and the creation of value and sustainable competitive advantage (Handfield et al., 2009; Hsu et al., 2011; Kickul et al., 2011; Li et al., 2011; Krishnan, 2013; Phan and Chambers, 2013). Entrepreneurship refers to the act of entering new or established markets with new ventures (Lumpkin and Dess, 1996; Van Praag, 1999). Some studies have investigated the role of entrepreneurship in the OM literature (e.g. Arend and Wisner, 2005; Song and di Benedetto, 2008; Song et al., 2011; Patel, 2011; Tatikonda et al., 2013). For example, Arend and Wisner (2005) analyse how supply chain management (SCM) fits 
with the capabilities and goals of new ventures. They found that SCM has a significant negative association with small and medium enterprise (SME) performance and call for future research to elaborate more on their preliminary results. Contrastingly, Song and di Benedetto (2008) and Song et al. (2011) found that supplier involvement is essential to successful innovation by new ventures. Elsewhere Patel (2011) investigated the relationship between formalized structures (where organizations must be able to reliably develop, manufacture and distribute products) and performance in new high-tech manufacturing SMEs. According to Patel, the liability of new ventures is their limited capacity to develop and maintain reliable structures. Despite this, new ventures must be flexible to cope with changing environments. Patel's findings show that enhanced performance in changing environments with manufacturing flexibility is contingent upon formalised structures. Tatikonda et al. (2013) investigated the relationship between operational capabilities and new venture survival considering the different life phases of a new venture's evolution. They found that operational capabilities (i.e., inventory turnover, gross margin and employee productivity) have an effect on new venture survival in specific new venture life phases.

It has been suggested that entrepreneurship is a broad concept that has not led to a widely held consensus in the entrepreneurship literature regarding its characterization (Lumpkin and Dess, 1996). To address this issue, the emphasis in the entrepreneurship literature has shifted towards entrepreneurial processes and the methods/skills managers can use to act entrepreneurially, namely entrepreneurial orientation (EO) (Lumpkin and Dess, 1996; Soininen et al., 2012). EO thus refers to the processes, practices, and decision-making activities that lead to new entry (Lumpkin and Dess, 1996; Rauch et al., 2009). A literature review reveals that innovativeness, proactivenes and risk taking are salient dimensions of EO (Richard et al., 2004; Rauch et al., 2009; Kreiser and Davis, 2012; Soininen et al., 2012). Innovativeness is the tendency to engage in creativity/experimentation through the introduction of new products/services, technology and R\&D. Proactiveness is an opportunity-seeking behaviour, characterised by the introduction of new products/services ahead of the competition in anticipation of future demand. Risk taking refers to taking bold actions and committing important resources to ventures in uncertain environments (Rauch et al., 2009). It has been argued that EO can be regarded as a multi-dimensional construct (Lumpkin and Dess, 1996); however, it has been equally suggested that EO is a unidimensional construct, and it 
should be analysed as such (Covin and Slevin, 1991). Meta-analyses of the entrepreneurship literature reveals that most studies have summed across innovativeness, proactiveness and risk taking to create an individual dimension of EO (Rauch et al., 2009; Rosenbusch et al., 2013). Further, it was found that these three dimensions are of equal importance explaining organizational performance across most studies, and thus it is reasonable to support the use of a summed index in future research (Covin et al, 2006; Rauch et al., 2009; Tang et al., 2009). Accordingly, consistent with Covin and Slevin $(1989 ; 1991)$, EO is represented in the current study as a unidimensional construct.

As noted earlier, there are a number of explicit connections and opportunities for the OM and entrepreneurship literature (Kickul et al., 2011; Joglekar and Levesque, 2013; Krishnan, 2013), and this should certainly be true at the intersection of OM and welldevelop entrepreneurship concepts such as EO (Lumpkin and Dess, 1996). It has been suggested that the development of operational capabilities can be positively affected by entrepreneurial behaviour (Giunipero et al., 2005; Kickul et al., 2011). Entrepreneurial firms characterized by tolerance to risk, innovativeness and proactiveness are more willing to adapt their business, creating capabilities to meet rapidly changing needs (Giunipero et al., 2005). For instance, high levels of uncertainty demand adaptive and flexible capabilities, which are supported by EO skills such as innovativeness and proactiveness (Giunipero et al., 2005). Further, there are traits of entrepreneurial behaviour that favour the creation of operational capabilities such as flexibility, agility, quality and efficiency, which are required to respond to market opportunities (Handfield et al., 2009; Hsu et al., 2011). At a supply chain level, EO can improve efficiency of knowledge acquisition ( $\mathrm{Li}$ et $\mathrm{al}, 2011$ ) to develop quality and efficiency oriented strategies (Hsu et al., 2001).

While EO has attracted a large stream of research and has become a central concept in the entrepreneurship domain (Rauch et al., 2009), research has begun to explore the need for EO in the OM domain (Giunipero et al., 2005). For instance, using historical analysis, Balakrishnan (2007) studied the factors that influenced the evolution of the Canadian manufacturing industry and found that entrepreneurial behaviour fostered the creation and subsequent growth of the early Canadian manufacturing industry. In another exploratory study Giunipero et al. (2005) developed an initial framework of 
skills by purchasing and supply management that emulate entrepreneurial behaviour. Giunipero et al. suggested that interpersonal communication, ability to make decisions, influencing and persuasion, and risk management are becoming increasingly important entrepreneurial skills required by SCM professionals in today's business environment. Handfield et al. (2009) explored the parallels between supply chain roles and entrepreneurial skills, and found key EO attributes manifest in SCM, namely supplier intelligence, supplier integration, cross-enterprise integration and supply management influence. Similarly, Hu et al. (2011) explored EO attributes in SCM (i.e. innovation orientation, risk-taking characteristics, proactiveness orientation, relational capital, and coordination capability) and found a positive association between these EO attributes and manufacturing SME performance. Using the contingency view, Goodale et al. (2011) studied the relationship between the antecedents to corporate entrepreneurship (i.e. management support, work discretion/autonomy, rewards/reinforcement, time availability and organizational boundaries), operations control attributes (i.e. risk control and process control formality) and innovation performance. While their results showed that antecedents to corporate entrepreneurship are not strong predictors of innovation performance, when operations controls attributes are taken into consideration, the effect of the antecedents to corporate entrepreneurship show a more significant influence on innovation performance. Thus, in accordance with the increasing interest of blended analysis across OM and entrepreneurship (Kickul et al., 2011) and calls for examining the contingency view of the traditional manufacturing capability-performance model (Sousa and Voss, 2008), we suggest EO as a possible contingency variable for the manufacturing capability- organizational performance link.

The contingency role of EO has been studied in the empirical entrepreneurship literature (e.g., Richard et al., 2004; Li et al., 2008); however, relatively less is known about the contingency role of EO in OM contexts. With regard to the contingency role of EO on the specific manufacturing capability-performance link, to our knowledge, the empirical evidence is fragmented and has concentrated on particular environmental conditions of the firm as contingency variables. However, it has been argued that environmental conditions can stimulate/impede entrepreneurial processes (Covin and Slevin, 1991).

Organizations respond to external environments (e.g., environmental munificence, hostility, complexity and dynamism) by entrepreneurial behaviour, which helps to 
exploit opportunities provided by the environment (Khandwalla, 1987; Rosenbusch et al., 2013). Specifically, entrepreneurial behaviour influences strategic decisions and actions that enable firms to successfully translate resources into capabilities to suit the environment (Rosenbusch et al., 2013). Entrepreneurial action stimulates strategic objectives and facilitates the combination of processes, the development of organizational structures, and acquisition of technologies on which specific capabilities are built (Lichtenstein and Brush, 2001; Covin and Lumpkin, 2011; Rosenbusch et al., 2013; Tatikonda et al., 2013; Ojha et al., 2016). Accordingly, it can be argued that EO stimulates firm-strategic objectives (e.g., quality focus, dependability, flexible response, competitive price) and supports the development of means through which capabilities such as manufacturing capabilities are built to pursue those objectives. In other words, EO can determine how manufacturing capabilities affect performance.

For instance, it has been argued that high EO is stimulated in environments characterized by environmental munificence (i.e., high growth, low competitive intensity, profitability and early stage in industry life cycle) (Tersejen et al., 2011; Rosenbusch et al., 2013). In such high-growth environments, superior product quality has been found to be a consistent strategy that generates competitive advantage among entrepreneurial firms (Covin et al., 2000). The opposite has been found in hostile environments (i.e., scarce resources and opportunities, fierce competition, low customer loyalty and profitability, and legal, political and economic constraints), where low EO can be an efficient response to hostility (Rosenbusch et al., 2013), and quality-based competition may not necessarily improve performance (Tersejen et al., 2011; Rosenbusch et al., 2013). Accordingly, high or low EO can stimulate firm-specific strategies such as a quality focus, and provide the means to develop matching capabilities to pursue those strategies (Tersejen et al., 2011; Rosenbusch et al., 2013). Formally, this gives the following hypothesis:

H2a: EO moderates the relationship between quality and organizational performance

With regard to delivery, dynamic environments where technology, demand and competition change suddenly would require a high degree of speed and dependability (Chi et al., 2009). Such environments encourage the implementation of proactive and innovative entrepreneurial postures that embody a focus on fast reaction, speed and the 
capability to alter the resource base (Rosenbusch et al., 2013). In contrast, stable environments may not require risky and explorative behaviour that focus on resource delivery and customer responsiveness. For instance, environments characterized by low product variety and short product life cycle do not necessarily require a proactive behaviour towards lead-time reduction and fast reaction (Fisher, 1997). Accordingly, varying levels of EO could determine how efficient delivery and speed capabilities are for performance improvement given the type of environment. It is thus hypothesises that:

$\mathrm{H} 2 \mathrm{~b}$ : EO moderates the relationship between delivery and organizational performance

With regard to flexibility, dynamic environments characterized by market uncertainty and unpredictability prompt EO behaviour such as a risky, proactive and explorative style, which support the creation of flexible capabilities to react to sudden changes (Rosensbusch et al., 2013). For instance, high entrepreneurial firms in dynamic environments promote flexible capabilities such as broader product lines (Covin et al., 2000). The opposite is required in relatively stable environments that do not necessarily require high $\mathrm{EO}$, and where flexible capabilities may not be a competitive asset (Rosensbusch et al., 2013). Nadkarni and Narayanan (2007) presented a model that considered the link between flexibility and organizational performance, moderated by the rate of innovativeness. Their findings suggest that highly innovative environments promote flexibility, reacting fast, and modifying their strategies to better suit environmental pressure. The opposite occurs in environments characterized by low innovativeness, where flexible capabilities can be superfluous and are not a determining factor in success. Accordingly, it is hypothesized that:

H2c: EO moderates the relationship between flexibility and organizational performance

With regard to cost, strategies characterised by effort to reduce inventory, improving productivity and streamlining operations are common responses in hostile environments (Covin et al., 2000; Rosenbusch et al., 2013). Hostile environments encourage high entrepreneurial response that supports effective cost leadership strategies such as the continuous investment in modern technology and automated processes (Covin et al., 2000). Empirical evidence shows that strategies characterized by strong cost capabilities such as lean manufacturing can have an effect on organizational performance when 
moderated by technological turbulence (Chavez et al., 2015a). Technological turbulence suggests a high degree of competitiveness, risk and uncertainty (Trkman and McCormack, 2009), and thus can reflect risk-taking entrepreneurial behaviour (Khandwalla, 1987). The opposite trend is found in benign and munificent environments where bases of competition other than cost tend to be more common and effective (e.g. quality) (Khandawalla, 1977). For instance, munificent environments encourage low entrepreneurial behaviour that supports cost superiority (Covin et al., 2000). Thus, firms that recognize the cost-sensitive nature of their market create low cost structures and capabilities, which are facilitated by varying levels of EO (Rosenbusch et al., 2013). This gives the following hypothesis:

$\mathrm{H} 2 \mathrm{~d}$ : EO moderates the relationship between cost and organizational performance

\section{Research methodology}

\subsection{Sampling and data collection}

The data for this study were gathered from China's manufacturing industry. With regard to the sample pool, we strategically chose five regions that represent different stages of economic development in China, including Pearl River Delta, Yangtze River Delta, Bohai Sea Economic Area, Central China, and Southwest China (Zhao et al., 2006). We drew our sample from China Enterprises Directory (2014). To obtain a representative sample, we randomly selected 1500 manufacturing firms from China Enterprises Directory (2014) across the five regions. We contacted the key informants by telephone and email before sending out the questionnaires to obtain their preliminary agreement to take part in the study. In order to ensure that the respondents were sufficiently knowledgeable to answer the questions, we identified a key informant in each randomly selected manufacturer who held a position such as CEO, president, director, or general manager. Most of the informants had been in their current position for more than five years. Thus, based on position and tenure it is reasonable to expect that the informants could offer deep insights into the functional activities and be knowledgeable about the content of the inquiry. The questionnaires with a cover letter explaining the main purpose of the study and assuring confidentiality were sent to the 1230 firms that agreed to participate and provide information for this research. After several reminders by phone calls and emails, a total of 337 questionnaires were received. Eight returned 
questionnaires were discarded because of significant missing data, which leads to 329 completed and useable questionnaires. The effective response rate was $26.75 \%$. Table 1 provides a summary of demographic characteristics of respondents. As shown in Table 1 , data were obtained from respondents in a wide variety of manufacturing firms, and the respondents represent a wide variety of backgrounds.

Insert Table 1 about here

\subsection{Non-response bias and common-method bias}

If respondents differ substantially from individuals who do not respond, then responses cannot be generalized to the population (Miller and Smith, 1983). However, it has been suggested that people responding in later waves can be assumed to be more similar to people who do not respond at all due to the extra stimulus used by the researcher to encourage completion of surveys (Armstrong and Overton, 1977; Lambert and Harrington, 1990). Five items used in the questionnaire were randomly selected to compare the first and last twenty returned questionnaires using the chi-square test. All the significance values of the selected items were above 0.01 , which implies an absence of non-response bias. Since the data were collected from single respondents, the potential for common-method bias was assessed. In order to identify the potential effects of common-method bias, the literature suggests the use of statistical techniques such as Harman's single-factor through exploratory factor analysis (EFA) (Podsakoff et al., 2003, Boyer and Hult, 2005). To conclude that common method bias is present either (a) a single factor will emerge from loading all variables into an EFA, or (b) one general factor will account for the majority of the covariance among measures (Podsakoff et al., 2003). The results of the EFA revealed 6 distinct factors, and the first factor explained $42 \%$ of the variance, which does not represent the majority of the total variance. To further assess common method bias, confirmatory factor analysis (CFA) was applied to Harman's single-factor model (Flynn et al., 2010). After conducting CFA, the model fit indices were poor $\left(\chi^{2} / \mathrm{df}=12.19, \mathrm{RMSEA}=0.184, \mathrm{CFI}=0.822\right.$ and $\mathrm{NNFI}=0.810)$ and significantly worse than those of the measurement model $\left(\chi^{2} / \mathrm{df}=\right.$ $3.28, \mathrm{RMSEA}=0.080, \mathrm{CFI}=0.964, \mathrm{NNFI}=0.960)$. This suggests that a single factor model is not acceptable and that common method bias is unlikely.

\subsection{Measures}


We surveyed the literature to identify valid measures for $E O$ (Covin and Slevin, 1989). The original Covin and Slevin scales included one item (i.e. our company typically adopts a very competitive "undo-the-competitors" posture), which measures competitive aggressiveness rather than proactiveness. Following Stam and Elfring (2008) and Lumpking and Dess (2001), we replaced this item with a question that emphasises leadership over the competition on introducing new ideas (i.e. our company has a strong tendency to be ahead of others in introducing novel ideas or products). Organizational performance was measured using scales on market and financial performance based on those developed by Flynn et al. (2010), and four dimensions of manufacturing capability (i.e. quality, delivery, flexibility and cost) were measured with scales based on Wong et al. (2011), Swink et al. (2007), Swink and Hegarty (1998) and Terjesen et al. (2011). The measures we used are listed in Table 2/3. All items pertaining to EO were measured on seven-point Likert scales from 1 (strongly disagree) to 7 (strongly agree), and respondents were asked to indicate the degree to which their organizations were characterized by EO behaviour. EO and how it contributes to performance has been viewed as an individual and firm-level phenomenon (Lumpking and Dess, 1996). However, the firm-level analysis corresponds to recent work that emphasizes the role of EO as a firm-level process, practices and decision-making style (Ashenbaum et al., 2012). Entrepreneurial behaviour has been regarded as a natural extension of individuals, who are in charge of the organization/unit or small business (Lumpking and Dess, 1996). As such, the current study focuses at the firm level. With regard to manufacturing capability, respondents were asked to evaluate the extent to which they agree or disagree with respect to their business' actual manufacturing capabilities using a seven-point Likert scale (being $1=$ strongly agree and $7=$ strongly disagree). With regard to organizational performance, our respondents were asked to assess their performance relative to the performance of main competitors over the last three years. The indicators were measured using a seven-point Likert scale $(1=$ much worse than your major competitor; $7=$ much better your major competitor), where higher values indicated better performance.

Since the measurement scales adapted from the literature were in English, the original scales were first developed in English, and then translated into Chinese by an operations management professor in China in order to ensure the reliability of the questionnaire 
(Zhao et al., 2011). The Chinese version of the questionnaire was then translated back into English by another operations management professor, and the translated English version was checked against the original English version for accuracy. A number of questions were reworded to improve the accuracy of the translation and to make it relevant to OM practices in China.

This study includes firm age as a control variable since research has suggested that younger firms may encounter more challenges in exploiting entrepreneurial opportunities and performance due to small resource bases (Stam and Elfring, 2008; Li et al., 2011). We therefore include firm age as the natural logarithm of the number of years since the firm was established.

\subsection{Measure validation and reliability}

The validation process for the survey instruments was completed in three steps: content validity, construct validity and reliability (O'Leary-Kelly and Vokurka, 1998). For content validity, before executing the survey, we sent the questionnaire to $\mathrm{OM}$ academics to review and provide feedback (O’Leary-Kelly and Vokurka, 1998). Based on the feedback, the modified version of the questionnaire was pilot-tested with the target population to verify its appropriateness for this group. Terminology was again adapted to better suit the target population.

We followed a two-step method to test construct validity (Narasimhan and Jayaram, 1998; Zhao et al., 2011). Construct validity was established through unidimensionality and discriminant validity. The implicit condition that a measure should satisfy in order to be considered unidimensional is that the measure must be associated with only one latent variable (O'Leary-Kelly and Vokurka, 1998). Unidimensionality was established first through the use of EFA with principal axis factoring, varimax rotation and extracting factors with eigenvalues greater than 1.0 (Tabachnick and Findell, 2001). Based on EFA, factor loadings for all items ranged from 0.401 (EO) to 0.884 (organizational performance) (see Table 2). Two items displayed lower factor loadings (i.e. there is a strong proclivity for high-risk projects with chances of very high return; owning to the nature of the environment, bold, wide-ranging acts are necessary to achieve the firm's objectives), which were not considered for further analysis to ensure 
the quality of the measures (Costello and Osborne, 2005). While one item of EO (i.e. typically we adopt a bold, aggressive posture in order to maximize the probability of exploiting potential opportunities) fell bellow the minimum of 0.5 as a common cut-off point (Anderson and Gerbing, 1988), we still satisfied the criteria of 0.4 set by other work such as Hair et al. (1998). More importantly, we decided to keep this item because it was the only item that reflected risk taking as a salient dimension of EO (Covin and Slevin, 1989; 1991). According to Miller (1983), EO is unidimensional and a firm could not be regarded as entrepreneurial if it innovates simply by imitating competitors while refusing to take any risk. Proactiveness would need to be considered too. By the same token, risk-taking firms (e.g. highly leveraged financially) are neither necessarily innovative nor proactive. Thus, all three dimensions are relevant to reflect EO. Accordingly, we decided to keep the item despite its relatively lower factor loading. The eigenvalues for the six factors are above 1.240 and the cumulative explained variance is $77.103 \%$. A Kaiser-Meyer-Olkin (KMO) statistic of 0.925 confirmed the suitability of the items for factor analysis since KMO values greater than 0.60 can be considered as adequate for applying factor analysis (Hair et al. 1998). Next, we used CFA to further test unidimentionality (Zhao et al., 2011). Lisrel 9.1 was used to carry out CFA. The standardised coefficients and t-values show that all the indicators are significantly related to the underlying construct (see Table 3 ). The average variance extracted (AVE) values were computed as the average squared standardized factor loadings (Hair 1998). Table 3 illustrates that values for all constructs are higher than 0.50 as a common cutoff value (Hair et al., 1998). CFA also allows examining the measurement model adequacy. The overall fit for the measurement model was good: of $\chi^{2} / \mathrm{df}=3.28$ and RMSEA $=0.080$. An RMSEA between 0 and 0.05 indicates a good fit, and less than 0.08 suggest a reasonable fit (Hair et al., 1998; Hu and Bentler 1999; Shin et al., 2000). Table 3 reports other relevant measures (i.e. $\mathrm{RMR}=0.0546$; NNFI $=0.960$; $\mathrm{CFI}=$ 0.964; IFI $=0.964, \mathrm{NFI}=0.949)$, which are also within an acceptable range (Kline, 2005, Hooper et al., 2008).

Discriminant validity was tested to measures the extent to which individual items, which intend to measure one latent construct, do not, at the same time, measure a different latent variable (DeVellis, 2003). Discriminant validity was tested first through inter-factor correlation (Anderson and Gerbing, 1988). While it is expected a degree of correlation, a very strong correlation between factors indicates that they are measuring 
the same construct (Anderson et al. 2002). Table 4 indicates that discriminant validity is unlikely (Anderson and Gerbing, 1988). As an alternative test, the correlation between two constructs was compared with the square root of AVE (Fornell and Larcker, 1981). According to this test, the correlation between each pair of constructs should be less than the square root of AVE for each individual construct (Li et al., 2011). Table 4 shows that none of the correlations is higher than the square root of AVE for each individual construct. Taken together, this provides evidence for the discriminant validity of our constructs.

Finally, in order to estimate reliability, the Cronbach's alpha coefficient was used, as it is a common method for assessing reliability in the empirical literature (Carmines and Zeller, 1979). Table 3 illustrates that all the scales show alpha values above 0.7, which indicates high levels of reliability (Nunnally, 1978).

\section{Data analysis and results}

The hypothesized relationships between the various constructs were analysed using ordinary least square (OLS) analyses. Prior to carrying out OLS, the data was tested for linearity and multicollinearity. First, linearity and equality of variables were assessed and confirmed through plotting the standardized residuals against the standardized predicted values (Field, 2009). Second, to test whether multicollinearity is present between the independent variables, the correlation coefficients were calculated. To indicate an absence of multicollinearity, a common cut-off value of 0.70 has been suggested (Anderson et al., 2002). Table 4 shows that the correlation coefficients between our independent variables are below this level. Furthermore, multicollinearity can be also concluded if the maximum variance inflation factor (VIF) exceeds ten as the common threshold (O'Brien, 2007). All variables in the model were consistently within this value (Max VIF $=2.898)$, which indicates multicollinearity is not a concern.

In order to test the relationship between manufacturing capabilities (i.e. quality, delivery, flexibility and cost) and organizational performance, and the moderating effect of EO on the relationship between manufacturing capabilities and organizational performance, OLS analyses were carried out following a hierarchical process (Zhao et al., 2011). In the first step, we entered the control variable. In the second step, we added 
the independent variables: quality, delivery, flexibility and cost and EO (the moderator variable). In the third step of the regression analysis, the interaction terms were introduced. Table 5 presents the results of the OLS regression analyses for the dependent variable: organizational performance.

First, we hypothesized in H1a-d that manufacturing capabilities (i.e. quality, delivery, flexibility and cost) were positively associated with organizational performance. Table 5 shows that, in the second step of the regression analysis, quality ( $\beta=0.005$, ns) and delivery $(\beta=0.024, \mathrm{~ns})$ are not significantly associated with organizational performance. Thus, H1a and H1b are not supported. However, flexibility $(\beta=0.207, \mathrm{p} \leq 0.01)$ and cost $(\beta=0.278, \mathrm{p} \leq 0.01)$ are significantly and positively associated with organizational performance, which indicates full support for H1c and H1d respectively. Second, we hypothesise in $\mathrm{H} 2 \mathrm{a}-\mathrm{d}$ that $\mathrm{EO}$ moderates the relationship between manufacturing capabilities and organizational performance. In the third step of the regression analysis, we entered the interaction terms to test our contingency hypotheses. The interaction terms: flexibility * $\mathrm{EO}(\beta=0.153 ; p \leq 0.05)$ and cost $* \mathrm{EO}(\beta=0.127 ; p \leq 0.05)$ were found to be significant and positive. Accordingly, there is full support for $\mathrm{H} 2 \mathrm{c}$ and $\mathrm{H} 2 \mathrm{~d}$. However, the lack of significance of the interaction terms: quality * EO $(\beta=-0.113$; ns) and delivery * EO ( $\beta=-0.050 ; \mathrm{ns})$ indicates that $\mathrm{H} 2 \mathrm{a}$ and $\mathrm{H} 2 \mathrm{~b}$ are not supported. Finally, as illustrated in Table 5, the first step of the regression analyses revealed that the effect of industry age, as a control variable, was not significant.

For the purpose of further confirmation, this study plotted the significant interaction effects. We conducted the simple slope analysis (Aiken and West, 1981) on the regressions of flexibility and cost on organizational performance at low (one SD below de mean) and high (one SD above the mean) levels of EO to test whether the slopes differ significantly from zero. The results show that flexibility is significantly associated with organizational performance when $\mathrm{EO}$ is high $(\beta=0.405, p \leq 0.01)$, but no significance was reported when EO is low $(\beta=-0.022$, ns). Similarly, results show that cost is significantly associated with organizational performance when $\mathrm{EO}$ is high $(\beta$ $=0.366, p \leq 0.01)$ than when EO is low $(\beta=0.023$, ns). Fig. 1 and 2 show that the impact of flexibility and cost on organizational performance is more pronounced when EO is high than when is low. We discuss these results in the following pages. 


\section{Discussion}

The main objectives of this study were to study the moderation effect of EO on the relationship between manufacturing capabilities (i.e. quality, delivery, flexibility and cost) and organizational performance. While support was found for some of the hypothesized relationships, our findings provide insights into the circumstances under which multiple manufacturing capabilities can enable organizational performance improvement; specifically in high EO contexts. Further, the findings contribute to the advancement of the RBV and CT perspectives in OM. The significance of these contributions will be discussed in the following paragraphs.

\subsection{Theoretical implications}

The empirical evidence supporting the relationship between manufacturing capability and organizational performance has been mixed (e.g., Rosenzweig et al., 2003; Lau Antonio et al., 2007; Swink et al., 2007). As such this study has sought to test a potentially missing variable that could explain differences in findings; namely EO. This study therefore complements the published empirical studies by illuminating EO's role in the manufacturing capability-performance model. Beginning with the non-moderated model, our results reveal a significant and positive relationship between flexibility and organizational performance. This suggests that harnessing organizational resources to deliver flexibility leads to a positive return in organizational performance. Thus flexibility resources are of strategic importance and a generative means of organizational performance (Rosenzweig et al., 2003). The results herein also substantiate a significant and positive relationship between cost capabilities and organizational performance. This suggests that the ability to manage and control costs throughout operations and the supply chain is a resource in the RBV sense since it leads to competitive advantage (Peng et al, 2008; Terjesen et al., 2011). Therefore, our results strengthen the view that cost and flexibility capabilities are resources enhancing organizational performance (Tracey et al., 1999; Rosenzweig et al., 2003).

Our results provided no evidence to support the contention that quality and delivery have a significant and positive effect on organizational performance. An interpretation 
of such a finding lies in the notion of 'order winners' and 'order qualifiers'. Originally developed by Hill (1993) in the manufacturing strategy literature, this view suggests that 'order qualifiers' are product features or organizational capabilities that only allow firms to enter or remain in the market. However, to outcompete competitors a business must possess specific capabilities that Hill called 'order winners'. The connection of this notion to our findings is critical because it suggests that quality and delivery may be seen as 'order qualifiers', and thus a precondition to market participation. Conversely, flexibility and cost can be considered as 'order winners' (Hill, 1993). As such the assets and processes associated with flexibility and cost are the organizational resources that can be leveraged to deliver competitive advantage and increased performance. Quality and delivery do not rise to the level of strategic resources in that they do not impact organizational performance. However, we caveat this cautioning that order qualifiers and winners are different in different contexts and change over time (Lau Antonio et al., 2007). As such, it is important for firms to remain vigilant and sensitive to the market so as to modify their resources as warranted by the market. Interestingly these attributes are not inconsistent with EO.

The Chinese context is of particular interest to us where flexibility seems to win orders Zhao et al., 2002) and cost-related capabilities are among the most strongly emphasized capabilities in certain clusters of manufacturers (Zhao et al., 2006). Given the robust growth of the Chinese manufacturing sector over the past two decades, this suggests that cost and flexibility are indeed very powerful capabilities to harness in emerging economies. It is possible, and worth future study, that these two capabilities are the most critical in new market and new product contexts.

While this study revealed the significance of flexibility and cost oriented resources, an important contribution is the value of EO as a resource. The results show that EO moderates the relationship between both flexibility and cost and organizational performance. In fact, so important is the role of EO that in contexts where EO is low, competitive advantage is not secured from employing flexibility and cost resources. This may be why there has been increasing interest in research into the intersection between entrepreneurship and OM (Handfield et al., 2009; Hsu et al., 2011; Kickul et al., 2011; Li et al., 2011); researchers have begun to perceive the criticality of EO. Thus, our study responds to the increased interest by offering the first empirical 
research investigating the role of EO in delivering improved organizational performance from manufacturing based resources.

Overall, the results support the contingency perspective and thus the importance of fit between characteristics of the environment (i.e. EO), practices and performance (Lawrence and Lorsch, 1967). What can be inferred from the results is that, flexibility and cost capabilities enable improvement in organizational performance when high EO characterizes organizational environments. In other words, environments characterized by high entrepreneurial behaviour (i.e. concurrently innovative, proactive and risk taking) facilitate the exploitation of manufacturing capabilities such as flexibility and cost, which, in turn, generate organizational performance improvement.

The contingency view highlights the importance of contingency factors and the danger of over-reliance on prescriptive research. According to Sousa and Voss (2008), OM practices and the learning about them have reached a matured stage, which has naturally raised doubts about its universal applicability. This stage of the OM theory-building process demands that more needs to be done in order to understand the true dynamics of the field (Voss et al., 1997). This view is compatible with the contingency premise that no universal set of strategic choices applies to every business situation (Lawrence and Lorsch, 1967), which naturally poses a threat to the one-way approach and suggests that there is no 'one-size-fits-all' way to organize a company's strategy (Ginsberg and Venkatraman, 1985). From a scientific theory-building process, predictability is a main concern, which occurs not only when researchers identify causal mechanisms that tie action to results, but also when circumstances under which the mechanism results in success are described (Christensen and Raynor, 2003). Our research has identified one such circumstance (i.e., EO), which supported and further developed the contingency view in $\mathrm{OM}$.

\subsection{Managerial implications}

Our study has also important managerial contributions. Our research has demonstrated that both flexibility and cost capabilities can be associated with organizational performance improvement. Flexibility may be important in that it may facilitate the creation of a closer fit between the product/service delivered and customer needs. 
Indeed, this is anecdotally supported by flexibility being regarded as a critical capability in market-driven economies (Zhao et al., 2002). To that end, the principle of fit is explained by Tracey et al. (1999), who report that the more precisely a product fits the customer needs, the greater the amount of sales are recognized. Essentially, the more the producer can respond to the customer's criteria, the greater percentage of the demand curve can be serviced. In regards to cost, our research suggests that the ability to manage and control costs throughout operations and the supply chain will facilitate the ability to offer competitive prices. This may reflect a different type of flexibility price flexibility. The ability to adjust price without long term detrimental impacts to profits also enables a greater percentage of demand to be captured. Firms able to reduce prices in the face of changing technology or competition will continue to be able to win orders. Given the finding, managers are encouraged to pursue investments directed toward increasing flexibility and the ability to control costs.

It has been suggested that capabilities such as quality and delivery are prerequisites and essential for some types of firms, e.g. automotive manufacturers such as Toyota, but that they cannot significantly improve performance (Lau Antonio et al., 2007). This is consistent with the findings of this study. An interpretation of such findings is that while flexibility and cost are critical capabilities to win orders quality and delivery may be fundamental to market participation. This interpretation should be considered with caution since order winners and qualifiers are time and market-specific (Lau Antonio et al., 2007). The question that remains is whether the global economy has changed in such a way that quality and delivery capabilities are no longer resources that can be leveraged for competitive advantage.

The consensus is that there are three primary competitive strategies: price, differentiation, and responsiveness. The findings of the present study suggest that capabilities around flexibility are facilitating responsiveness and possibly even differentiation. The capabilities around cost are facilitating a price strategy. Capabilities around quality are not sufficient to differentiate the products in the market and reliability of delivery is not as important as the ability to modify delivery dates, quantities, and item configuration. Moreover, beyond just the capability to be flexible or low cost is the role of EO. It may well be the role of EO that connects and leverages the capabilities in manufacturing with firm level strategy to deliver results better than the 
competition. For ventures and young firms, manufacturing capabilities such as cost are usually not fully developed since they require factors such as complex resource interaction, structures and organizational routines that support the creation of capabilities and enhance the value of existing ones (Terjesen et al., 2011). The development of these factors could be supported by proactive entrepreneurial behaviour (Rosenbusch et al., 2013) such as the introduction of administrative techniques and processing technologies before the competition. Further, ventures and new firms often lack resources such as expensive processes and technologies, which are required to build manufacturing capabilities (Terjesen et al., 2011). Entrepreneurial posture such as proactivity, risk-taking and innovativeness could be conducive to acquiring technologies and other tangible assets on which capabilities are often built (Rosenbusch et al., 2013). This can be further illustrated by the example of certain environments, which stimulate entrepreneurial behaviour (Covin and Slevin, 1991) and shape manufacturing capability (Tersejen et al., 2011). For instance, industries characterised by permanent change and flexible manufacturing structures (Nadkarni and Narayanan, 2007) stimulate complementary entrepreneurial postures such as strong innovativeness and technological leadership (Khandwalla, 1987; Rosenbusch et al., 2013) to be able to react fast to suit better environmental pressure (Nadkarni and Narayanan, 2007). For example, Hitachi, which operates in the innovative high-tech industry, decided to move beyond operating partnerships to a more proactive posture towards strategic supplier relationship in order to customize manufacturing processes and new products with short lead times, and thus more accurately fulfil specification of customer requirements (Vonderembse et al., 2006).

The context of the present study is the Chinese manufacturing industry, which faces fierce competition forcing rapid development of manufacturing capabilities (Zhao, et al., 2002). An investigation of Chinese manufacturing industry trends reveals that flexibility and cost are critical capabilities among Chinese enterprises and both could become an essential combination to compete in the following years (Zhao, et al., 2002). However, this study reveals too that entrepreneurial environments characterized by permanent innovation, proactive behaviour towards competition, and the adoption of high-risk strategies to maximize opportunities, could better shape or facilitate the adoption/development of flexible and cost-oriented manufacturing capabilities, which will, in turn, improve organizational performance. Accordingly, practitioners should 
evaluate the level of EO in their enterprises before pursuing flexible and cost-oriented manufacturing strategies. Alternatively, if a practitioner already focuses on flexibilityand cost-oriented manufacturing strategies, they are advised to encourage an EO posture in their firms.

On a macroeconomic scale, our study may provide insights into the success of the Chinese economy over the last several decades. Specifically, this research has found that capabilities in regards to cost and flexibility to be important to gaining competitive advantage. These attributes are almost synonymous with China's manufacturers. Additionally, anecdotal evidence is rampant across the globe as to the entrepreneurial spirit of the Chinese people, which is deeply rooted in their culture and history (e.g., the importance placed on reputation achieved through hard work and successful enterprise) (Zapalska and Edwards, 2001). One interpretation of our research is that the entrepreneurialism of the Chinese people has created an EO within Chinese companies that in conjunction with developing capabilities around flexibility and cost is a part of the explanation of China's success in driving the unprecedented growth of its economy.

\section{Conclusion}

While research on the traditional manufacturing capability-performance model is voluminous, empirical results are sometimes inconclusive. An interpretation of the inconsistency in results may lie within the contingency view (Sousa and Voss, 2008). Studies have also called for blended analysis across OM and entrepreneurship (Kickul et al., 2011). This study contributes positively to theory by confirming the moderating role of EO on the relationship between flexibility and organizational performance, and between cost and organizational performance. Thus, this study offers a possible explanation as to why prior studies did not find performance benefits from manufacturing capabilities. Further this study furthers insight into the intersection between the OM and entrepreneurship. Specifically, our study expands the EO perspective in OM by explaining how EO complements manufacturing capabilities to improve organizational performance.

While this study contributes to theory and practice, there are certain limitations that should be considered. In this study, we focused on three dimensions of EO, namely 
innovativeness, proactivenes and risk taking. The literature suggests additional dimensions such as autonomy and competitive aggressiveness (Lumpking and Dess, 1996) that could complement EO in future studies. Further, it has been argued that EO can be a multi-dimensional construct with different individual and combined impacts (Lumpkin and Dess, 1996). Future research may consider the latter aspect for testing a wider perspective of EO. Finally, our results are valid only in the context of the Chinese manufacturing industry. However, while EO has been widely studied in the U.S context and other developed economies; much less examination has been conducted in an emerging fast-growth economy like China (Tang et. al, 2008). China is very different in that factors such as guanxi, the lack of experienced management teams and the role of formalization, and the coexistence of socialist and market-based capitalist system may have an effect on the nature and impact of EO (Tang et al., 2008). Thus, our findings also contribute to the understanding of EO and its relationship to manufacturing strategy in a distinctive but motivating economic context.

\section{References}

Aiken, L.S. West, S.G., 1991. Multiple regression: testing and interpreting interactions, Sage Publications, Inc Newbury Park, California, CA.

Anderson, D.R., Sweeney, D.J., Williams, T.A., 2002. Statistics for business and economics. Cincinnati, OH: South-Western: Thomson Learning Publishing Company.

Anderson, J.C., Gerbing, D.W., 1988. Structural equation modeling in practice: a review and recommended two-step approach. Psychological Bulletin, 103 (3), 411-423.

Arend, J.A., Wisner, J.D., 2005. Small business and supply chain management: Is there a fit? Journal of Business Venturing, 20, 403-436.

Armstrong, J.S., Overton, T.S., 1977. Estimating non-response bias in mail Surveys. Journal of Marketing Research, 14 (3), 396-402.

Ashenbaum, B, Salzarulo, P.A., Rocky Newman, W., 2012. Organizational structures, entrepreneurial orientation and trait preference in transportation brokerage firms. Journal of Supply chain Management, 48 (1), 3-23.

Azadegan, A, Patel, P. C., Zangoueinezhad, A., Linderman, K., 2013. The effect of environmental complexity and environmental dynamism on lean practices. Journal of Operations Management, 31 (4), 193-213.

Balakrishnan, J., Eliasson, J.B., Sweet, R.C.T., 2007. Factors affecting the evolution of manufacturing in Canada: An historical perspective. Journal of Operations Management, 25, 260-283. 
Beamon, B., 1999. Measuring supply chain performance. International Journal of Operations \& Production Management, 19 (3), 275-292.

Boon-itt, S., Wong, C.Y., 2016. Empirical investigation of alternate cumulative capability models: A multi-method approach. Production Planning and Control 27 (4), 299-311.

Boyer, K., Lewis, M., 2002. Competitive priorities: Investigating the need for trade-offs in operations strategy. Production and Operations Management 11(1), 9-20.

Boyer, K.K. and Hult G.T., 2005. Extending the supply chain: Integrating operations and marketing in the online grocery industry. Journal of Operations Management, 23(6), 642-661.

Carmines, E., Zeller, R., 1979. Reliability and validity assessment. California: SAGE Publications University Papers.

Chan, F., 2003. Performance measurement in a supply chain. International Journal of Advanced Manufacturing Technology, 21 (7), 534-548.

Chang, H.H., 2009. An empirical study of evaluating supply chain management integration using the balanced score card in Taiwan. Service Industries Journal, 29, 185202.

Chavez, R., Yu, W., Jacobs, M., Fynes, B., Wiengarten, F., Lecuna, A., 2015a. Internal lean practices and performance: The role of technological turbulence. International Journal of Production Economics, 160 (2), 157-171.

Chavez, R., Yu, W., Gimenez, C., Fynes, B., Wiengarten, F., 2015b. The relationship between customer integration and operational performance: The role of information quality. Decision Support Systems, 80 (12), 83-95.

Chen, I.J., Paulraj, A., 2004. Understanding supply chain management: Critical research and a theoretical framework. International Journal of Production Research, 42 (1), 131163.

Chi, T., Kilduff, P.D., Gargeya, V.B., 2009. Alignment between business environment characteristics, competitive priorities, supply chain structures, and firm business performance. International Journal of Productivity and Performance Management, 58 (7), 645-669.

China Enterprises Directory, 2014. Database of Provinces. EMAGE Company.

Christensen, C., Raynor, M., 2003. Why hard-nosed executives should care about management theory. Harvard Business Review, 81 (9), 67-74.

Costello A.B., Osborne, J.W., 2005. Best practices in exploratory factor analysis: four recommendations for getting the most form your analysis. Practical Assessment, Research and Evaluation, 10 (7), 1-9. 
Covin, J.G., Slevin, D.P., 1991. A conceptual model of entrepreneurship as firm behaviour. Entrepreneurship Theory and Practice, 16 (1), 7-25.

Covin, J.G., Slevin, D.P., 1989. Strategic management of small firms in hostile and benign environments. Strategic Management Journal, 10, 75-87.

Covin, J.G., Slevin, D.P., Heeley, M.B., 2000. Pioneers and followers: Competitive tactics, environment, and firm growth. Journal of Business Venturing, 15 (2), 175-210.

Covin, J.G., Green, K.M., Slevin, D.P., 2006. Strategic process effects on the entrepreneurial orientation-sales growth rate relationship. Entrepreneurial Theory and Practice, 30 (1), 57-81.

Covin J.G., Lumpkin, G.T., 2011. Entrepreneurial orientation theory and research: Reflection on a needed construct. Entrepreneurial Theory and Practice, 35 (5), 855-872.

Curkovic, S., Vickery, S., Droge, C., 2000. An empirical analysis of the competitive dimensions of quality performance in the automotive supply industry. International Journal of Operations \& Production Management, 20 (3-4), 386-408.

De Toni A., Tonchia, S., 2001. Performance measurement systems: Models, characteristics and measures. International Journal of Operations \& Production Management, 21 (1-2), 46-70.

DeVellis, R.F., 2003. Scale development: Theory and applications. California, CA: Sage, Newbury Park

Droge, C., Jacobs, M., Vickery, S., 2012. An empirical study: Does supply chain integration mediate the relationship between product/process strategy and service performance? International Journal of Production Economics, 137 (2), 250-262.

Eisenhardt, K., Martin, J., 2000. Dynamic capabilities: what are they? Strategic Management Journal, 21 (10/11), 1105-1121.

Fawcett, S., Calantone, R., Roth, A. 2000. Meeting quality and cost imperatives in a global market. International Journal of Physical Distribution \& Logistics Management, 30 (6), 472-499.

Fiegenbaum, A., Karnani, A., 1991. Output flexibility: A competitive advantage for small companies. Strategic Management Journal, 12 (2), 101-114.

Field, A.P., 2009. Discovering statistics using SPSS for Windows: Advanced techniques for the beginner. London, UK: SAGE publications Ltd.

Fisher, M., 1997. What is the right supply chain for your product? Harvard Business Review, 75(2), 105-117.

Flynn, B., Schroeder R., Flynn, E.J., 1999. World class manufacturing: An investigation of Hayes and Wheelwright's foundation. Journal of Operations Management, 17 (3), 249-269. 
Flynn, B.B., Huo, B., Zhao, X., 2010. The impact of supply chain integration on performance: A contingency and configuration approach. Journal of Operations Management, 28 (1), 58-71.

Fredericks, E., 2005. Infusing flexibility into business-to-business firms: A contingency theory and resource-based view perspective and practical implications. Industrial Marketing Management, 34 (6), 555-565.

Fynes, B, deBurca, S., Voss, C., 2005. Supply chain relationship quality, the competitive environment and performance. International Journal of Production Research, 43 (16), 3303-3320.

Gerwin, D., 1993. Manufacturing flexibility: A strategic perspective. Management Science, 39 (4), 395-410.

Ginsberg, A., Venkatraman, N. 1985. Contingency perspective of organizational strategy: A critical review of the empirical research. Academy of Management Review, $10(3), 421-434$.

Giunipero, L.C., Denslow, D., Eltantawy, R., 2005. Purchasing/supply chain management flexibility: Moving to an entrepreneurial skill set. Industrial Marketing Management, 34, 602-313.

Goodale, J.C., Kratko, D.F., Horsby, J.S., Covin, J.G., 2011. Operations management and corporate entrepreneurship: The moderating effect of operations control on the antecedents of corporate entrepreneurial activity in relation to innovation performance. Journal of Operations Management, 29, 116-127.

Gunasekaran, A., Patel, C., McGaughey, R. 2004. A framework for supply chain performance measurement. International Journal of Production Economics, 87 (3), 333347.

Hair Jr., J., Anderson, R., Tatham, R., Black, W., 1998. Multivariate data analysis. 5th Ed. U.S.A: Prentice-Hall, Inc.

Handfiled, R., Petersen, K, Cousins, P., Lawson, B., 2009. An organizational entrepreneurship model supply management integration and performance outcomes. International Journal of Operations and Production Management, 29 (2), 100-126.

Hayes, R.H., Wheelwright, S.C., 1984. Restoring our Competitive Edge: Competing Through Manufacturing, John Wiley \& Sons, New York, NY.

Hill, T., 1993. Manufacturing strategy: The strategic management of the manufacturing function, Macmillan London, 2nd Ed.

Ho, C.K.D, Au, K.F., Newton, E., 2002. Empirical research on supply chain management: a critical review and recommendations. International Journal of Production Research, 40 (17), 4415-4430. 
Hofer, C., 1975. Towards a contingency theory of business strategy. Academy of Management Journal, 18 (4), 784-810.

Holweg, M., Pil, F.K., 2005. Flexibility first: Keeping the automotive supply chain responsive through build-to-order. Industrial Engineer, 37 (6) 46-52.

Hooper, D., Coughlan, J. and Mullen, M., 2008. Structural equation modelling: guidelines for determining model fit. Electronic Journal of Business Research Methods, $6(1), 53-60$.

Hsu , C.C., Tan, K.C., Laosirihongthong, T., Leong, K., 2011. Entrepreneurial SCM competence and performance of manufacturing SMEs. International Journal of Production Research, 49 (22), 6629-6649.

Hu, L., Bentler, P.M., 1999. Cut-off criteria for fit indexes in covariance structure analysis: conventional criteria versus new alternatives. Structural Equation Modelling: A Multidisciplinary Journal, 6 (1), 1-55.

Jacobs, M., Droge, C., Vickery, S., Calantone, R., 2011. The effect of product and process modularity on agility and firm growth performance. Journal of Product Innovation Management, 28 (1), 124-138.

Jacobs, M., Vickery, S., Droge, C., 2007. The effects of product modularity on competitive performance: Do integration strategies mediate the relationship? International Journal of Operations \& Production Management, 27 (10), 1046-1068.

Joglekar, N., Levesque, M., 2013. The role of operations management across the entrepreneurial value chain. Production and Operations Management, 22 (6), 13211335.

Kannan, V.R., Tan, K.C., 2005. Just in time, total quality management, and supply chain management: understanding their linkages and impact on business performance. Omega, 33 (2), 153-162.

Kerlinger, F.R., 1986. Foundations of Behavioral Research. Holt: Rinehart and Winston, Inc., Fort Worth.

Ketokivi, M.A., Schroeder, R.G. 2004. Perceptual measures of performance: Fact or fiction? Journal of Operations Management, 22 (3), 247-264.

Khandwalla, P.N., 1987. Generators of pioneering-innovative management: Some Indian evidence". Organization Studies, 8 (1), 35-59.

Khandwalla, P.N., 1977. The Design of Organizations. New York: Hardcourt Brace Jovanovich.

Kickul, J.R., Griffiths, M. D., Jayaram, J., Wagner, S.M., 2011. Operations management, entrepreneurship, and value creation: Emerging opportunities in a crossdisciplinary context. Journal of Operations Management 29 (1-2), 78-85. 
Kim, S.W., 2006. Effects of supply chain management practices, integration and competition capability on performance. Supply Chain Management: An International Journal, 11 (3), 241-250.

Kline, R.B., 2005. Principles and practice of structural equation modelling, New York, NY: The Guilford Press.

Krause, D., Pagell M., Curkovic, S., 2001. Toward a measure of competitive priorities for purchasing. Journal of Operations Management, 19 (4), 497-512.

Kreiser P.M., Davis, J., 2010. Entrepreneurial orientation and firm performance: The unique impact of innovativeness, proactiveness, and risk-taking. Journal of Small Business and Entrepreneurship, 23 (1), 39-51.

Krishnan, V., 2013. Operations Management Opportunities in Technology Commercialization and Entrepreneurship. Production and Operations Management, 22 (6), 1439-1445.

Lambert, D.M., Harrington, T.C., 1990. Measuring non-response bias in customer service mail surveys. Journal of Business Logistics, 11 (2), 5-25.

Lau Antonio, K.W., Yam, R., Tang, E., 2007. The impacts of product modularity on competitive capabilities and performance: An empirical study. International Journal of Production Economics, 105 (1), 1-20.

Lavie, D., 2006. The competitive advantage of interconnected firms: An extension of the resource-based view. Academy of Management Review, 31 (3), 638-658.

Lawrence, P., Lorsch, J., 1967. Differentiation and integration in complex organizations. Administrative Science Quarterly, 12 (1), 1-47.

Li, L.L.X., 2000. Manufacturing capability development in a changing business environment. Industrial Management \& Data Systems, 100 (6), 261-270.

Li, S., Subba Rao, S., Ragu-Nathan, B., Ragu-Nathan, T., 2005. Development and validation of measurement instruments for studying supply chain management practices. Journal of Operations Management, 23 (6), 618-641.

Li, Y, Liu, Y., Liu, H., 2011. Co-opetition, distributor's entrepreneurial orientation and manufacturer's knowledge acquisition: Evidence from China. Journal of Operations Management, 29, 128-142.

Li, Y, Zhao, Y, Tan, J., Liu, Y., 2008. Moderating effect of entrepreneurial orientation on market orientation-performance linkage: Evidence from Chinese small firms. Journal of Small Business Management, 46 (1), 113-133.

Lichtenstein, B.M.B., Brush, C.G., 2001. How do 'resource bundlers' develop and change in new ventures? A dynamic model and longitudinal exploration. Entrepreneurship Theory and Practice, 25(3), 37-58. 
Lumpkin G.T., Dess, G.G., 1996. Clarifying the entrepreneurial orientation construct and linking it to performance. Academy of Management Review, 21 (1), 135-172.

Lumpkin, G.T., Dess, G.G., 2001, Linking two dimensions of entrepreneurial orientation to firm performance: The moderating role of environment and industry life cycle. Journal of Business Venturing, 16, 429-451.

Melnyk, S.A., Handfield, R.B., 1988. May you live in interesting times ... the emergence of theory-driven empirical research. Journal of Operations Management 16 (4), 311-319.

Miller, D., Shamsie, J., 1996. The resource-based view of the firm in two environments: the Hollywood film studio from 1936 to 1965. Academy of Management Journal, 39 (3), 519-543.

Miller, L.E., Smith. K.L., 1983. Handling nonresponse issues. Journal of Extension, 21 (59), 45-50.

Nadkarni, S., Narayanan, V., 2007. Strategic schemas, strategic flexibility, and company performance: The moderating role of industry clockspeed. Strategic Management Journal, 28 (3), 243-270.

Narasimhan, R., Das, A., 2001. The impact of purchasing integration and practices on manufacturing performance. Journal of Operations Management, 19 (5), 593-609.

Narasimhan, R., Jayaram, J., 1998. Causal linkage in supply chain management: An exploration study of North American manufacturing companies. Decision Sciences, 29 (3), 579-605.

Nunnally, J.C., 1978. Psychometric theory. New York, NY: McGraw-Hill Inc.

O'Brien, R.M., 2007. A caution regarding rules of thumb for variance inflation factors. Quality and Quantity, 41 (5), 673-90.

Ojha, D., Shockley, J., Acharya, C., 2016. Supply chain organizational infrastructure for promorting entrepreneurial emphasis and innovativeness: The role of trust and learning. International Journal of Production Economics, 179, 212-227.

O'Leary-Kelly, S.W., Vokurka, R.J., 1998. The empirical assessment of construct validity. Journal of Operations Management, 16 (4), 387-405.

Phan, P., Chambers, C., 2013. Advancing theory in entrepreneurship from lens of operations management. Production and Operations Management, 22 (6), 1423-1428.

Patel, P., 2011. Role of manufacturing flexibility in managing duality of formalization and environmental uncertainty in emerging firms. Journal of Operations Management, 29, 143-162.

Peng, D.X., Schroeder, R.G. and Shah, R., 2008. Linking routines to operations capabilities: A new perspective. Journal of Operations Management, 26 (6), 730-748. 
Podsakoff, P.M., MacKenzie, S., Lee, J.Y., Podsakoff, N.P., 2003. Common method biases in behavioural research: A critical review of the literature and recommended remedies. Journal of Applied Psychology, 88 (5), 879-903.

Porter, M.E., 1991. Towards a dynamic theory of strategy. Strategic Management Journal, 12, 95-117.

Rauch, A., Wiklund, J, Lumpkin, G.T., Frese, M., 2009. Entrepreneurial orientation and business performance: An assessment of past research and suggestions for the future. Entrepreneurship Theory and Practice, 33 (3), 761-787.

Richard, O., Barnett, T., Dwyer. S., Chadwick, K., 2004. Cultural diversity in Management, firm performance, and the moderating role of entrepreneurial orientation dimensions. The Academy of Management Journal, 47 (2), 255-266.

Rosenbusch, N., Rauch, A., Bausch, A., 2013. The mediating role of entrepreneurial orientation in the task environment-performance relationship: A meta-analysis. Journal of Management, 39 (3), 633-659.

Rosenzweig, E., Roth, A., Dean, J.W., 2003. The influence of an integration strategy on competitive capabilities and business performance: An exploratory study of consumer products manufacturers. Journal of Operations Management, 21 (4), 437-456.

Sanders, N.R., 2007. An empirical study of the impact of e-business technologies on organizational collaboration and performance. Journal of Operations Management, 25 (6), 1332-1347

Santos Bernardes, E., Hanna, M.D., 2008. A theoretical review of flexibility, agility and responsiveness in the operations management literature, International Journal of Operations and Production Management, 29 (1), 30-53.

Schmenner, R.W., Tatikonda, M.V., 2005. Manufacturing process flexibility revisited. International Journal of Operations \& Production Management, 25 (12), 1183-1190.

Schoonhoven, C., 1981. Problems with contingency theory: Testing assumptions hidden within the language of contingency theory. Administrative Science Quarterly 26 (3), 349-377.

Shin, H., Collier, D., Wilson, D., 2000. Supply management orientation and supplierbuyer performance. Journal of Operations Management, 18 (3), 317-333.

Singhal, K., Singhal, J., 2012. Imperatives of science of operations and supply-chain management. Journal of Operations Management, 30, 237-244.

Skinner, W., 1969. Manufacturing - missing link in corporate strategy. Harvard Business Review, 47 (3), 136-145.

Slack, N., Chambers, S., Johnston, R., Betts, A., 2009. Operations and process management: Principles and practices for strategic impact. London, 2nd Ed.: Pearson Education. 
Song, L.Z., Song, M., Di Benedetto, A.C., 2011. Resources, supplier investment, product launch advantage, and first product performance. Journal of Operations Management, 29, 86-104.

Soininen, J., Marikainen, M, Puumalainen, K., Kylaheiko, K., 2012. Entrepreneurial orientation: Growth and profitability of Finnish small- and medium-sized enterprises. International Journal of Production Economics, 140 (2), 614-621.

Sousa, R., Voss, C., 2008. Contingency research in operations management practices. Journal of Operations Management, 26 (6), 697-713.

Spina, G., Verganti, R., 2002. Factors influencing co-design adoption: Drivers and internal consistency. International Journal of Operations \& Production Management, 22 (12), 1354-1366.

Stam, W., Elfring, T., 2008. Entrepreneurial orientation and new venture performance: The moderating role of intra- and extraindustry social capital. Academy of Management Journal, 51 (1), 97-111.

Swink, M., Hegarty, H., 1998. Core manufacturing capabilities and their link to product differentiation. International Journal of Operations \& Production Management, 18 (4), 374-396.

Swink, M. Narasimhan, R., Kim, S.W., 2005. Manufacturing practices and strategy integration: Effects on cost efficiency, flexibility, and market-based performance. Decision Sciences, 36 (3), 427-457.

Swink, M., Narasimhan, R., Wang, C., 2007. Managing beyond the factory walls: Effects of four types of strategic integration on manufacturing plant performance. Journal of Operations Management, 25 (1), 148-164.

Tabachnick, B., Fidell, L., Osterlind, S., 2001. Using multivariate statistics. 4th Ed., Boston: Allyn and Bacon.

Tang, J, Tang, Z, Marino, L.D., Zhang, Y., Li, Q., 2008. Exploring and inverted Ushape relationship between entrepreneurial orientation and performance in Chinese ventures. Entrepreneurship Theory and Practice, 32 (1), 219-239.

Terjesen, S., Patel, P.C., Covin, J.G., 2011. Alliance diversity, environmental context and the venture of manufacturing capabilities among new high technology ventures. Journal of Operations Management, 29, 105-115.

Tatikonda, M.V., Terjesen, S.A, Patel, P.C., Parida, V., 2013. The role of operational capabilities in enhancing new venture survival: A longitudinal study. Production and Operations Management, 22 (6), 1401-1415

Tracey, M., Lim, J., Vonderembse, M., 2005. The impact of supply-chain management capabilities on business performance. Supply Chain Management: An International Journal, 10 (3), 179-191. 
Tracey, M., Vonderembse, M., Lim, J.S., 1999. Manufacturing technology and strategy formulation: Keys to enhancing competitiveness and improving performance. Journal of Operations Management, 17 (4), 411-428.

Trkman, P., McCormack, K., 2009. Supply chain risk in turbulent environments-A conceptual model for managing supply chain network risk. International Journal of Production Economics, 119 (2), 247-258.

Van Praag, C.M., 1999. Some classic views of entrepreneurship. De Economist, Vol. $147,311-335$.

Voss, C., Åhlström, P., Blackmon, K., 1997. Benchmarking and operational performance: Some empirical results. International Journal of Operations and Production Management, 17(10), 1046-1058.

Vonderembse, M., Uppal, M., Huang, S., Dismukes, J., 2006. Designing supply chains: Towards theory development. International Journal of Production Economics, 100 (2), 223-238

Walter A., Auer, M., Ritter, T., 2006. The impact of network capabilities and entrepreneurial orientation on university spin-off performance. Journal of Business Venturing, 21, 541-567.

Ward, P., Leong, G.K., Boyer, K., 1994. Manufacturing proactiveness and performance. Decision Sciences, 25 (3), 337-358.

Ward, P., McCreery, J., Ritzman, L., Sharma, D., 1998. Competitive priorities in operations management. Decision Sciences, 29 (4), 1035-1046.

Wernerfelt, B., Karnani, A., 1987. Competitive strategy under uncertainty. Strategic Management Journal, 8, 187-194.

Wheelright, S.C., 1984. Manufacturing strategy: Defining the missing link. Strategic Management Journal, 5, 77-91.

Whetten, D., 1989. What constitutes a theoretical contribution? Academy of Management Review, 14 (4), 490-495.

White, G.P., 1996. A meta-analysis model of manufacturing capabilities, Journal of Operations Management, 14 (4), 315-331.

Wiengarten, F., Pagell, M., Usman Ahmend, M, Gimenez, C., 2013. Do country’s logistical capabilities moderate the external integration performance relationship? Journal of Operations Management 32 (1-2), 51-63.

Womack, J.P., Jones, D.T., 1994. From lean production to the lean enterprise. Harvard Business Review, 72 (2), 93-103. 
Wong, C.Y., Boon-itt, S. and Wong, C. W.Y., 2011. The contingency effect of environmental uncertainty on the relationship between supply chain integration and operational performance. Journal of Operations Management, 29 (6), 604-615.

Worren, N., Moore, K., Cardona, P., 2002. Modularity, strategic flexibility, and firm performance: A study of the home appliance industry. Strategic Management Journal, 23 (12), 1123-1140.

Yu, W., Ramanathan, R., Nath, P., 2014. The impacts of marketing and operations capabilities on financial performance in the UK retail sector: A resource-based perspective. Industrial Marketing Management, 43 (1), 25-31.

Zapalska, A.M., Edwards, W., 2001. Chinese entrepreneurship in a cultural and economic perspective. Journal of Small Business Management, 39 (3), 286-292.

Zhao X, Huo, B., Selend W, Yeung J.H.Y., 2011. The impact of internal integration and relationship commitment on external integration. Journal of Operations Management, 29, 17-32.

Zhao, X., Huo, B., Selen, W., Hoi Yan Yeung, J., 2011. The impact of internal integration and relationship commitment on external integration. Journal of Operations Management, 29, 17-32

Zhao, X., Flynn, B.B., Roth, A.V., 2006. Decision sciences research in China: A critical review and research agenda-foundations and overview. Decision Sciences, 37 (4), 451496.

Zhao, X., Sum, C.C, Qi, Y., Zhang, H., Lee, T.S., 2006. A taxonomy of manufacturing strategies in China, Journal of Operations Management, 24, 621-636.

Zhao, X., Yeung, J., Zhou, Q., 2002. Competitive priorities of enterprises in Mainland China. Total Quality Management, 13 (3), 285-300. 
Table 1: Demographic characteristics of respondents $(n=329)$

\begin{tabular}{lll}
\hline & Number of firms & Percent $(\%)$ \\
\hline Industries & 113 & 34.3 \\
Automobile & 50 & 15.2 \\
Chemicals and petrochemicals & 26 & 7.9 \\
Electronics and electrical & 8 & 2.4 \\
Fabricated metal product & 9 & 2.7 \\
Food, beverage and alcohol & 13 & 4.0 \\
Rubber and plastics & 110 & 33.4 \\
Textiles and apparel & & \\
Number of employees & 56 & 17.0 \\
$1-100$ & 36 & 10.9 \\
$101-200$ & 65 & 19.8 \\
$201-500$ & 27 & 8.2 \\
$501-1000$ & 54 & 16.4 \\
$1001-3000$ & 91 & 27.7 \\
$>3000$ & & \\
Firm age (years) & 103 & 31.3 \\
$\leq 10$ & 104 & 31.6 \\
$11-20$ & 35 & 10.6 \\
$21-30$ & 87 & 26.4 \\
$>30$ & & \\
Respondent location (geographical regions) & 17 & 5.2 \\
Pearl River Delta* & 33 & 10.0 \\
Yangtze River Delta & 22 & 6.6 \\
Bohai Sea Economic Area & 27 & 8.2 \\
Central China & 230 & 69.9 \\
Southwest China & & 41.3 \\
Years in current position & 136 & 30.7 \\
6-10 & 101 & 28.0 \\
$>10$ & 92 & \\
\hline
\end{tabular}

Note: * It includes one firm in Taiwan and one firm in Hong Kong.

Table 2: Inter-factor correlations

\begin{tabular}{lcccccccc}
\hline \multicolumn{1}{c}{ Construct } & Mean & S.D. & $\mathbf{1}$ & $\mathbf{2}$ & $\mathbf{3}$ & $\mathbf{4}$ & $\mathbf{5}$ & $\mathbf{6}$ \\
\hline 1. Quality & 5.341 & 1.133 & $\mathbf{0 . 8 7 4}$ & & & & & \\
2. Delivery & 5.288 & 1.128 & $0.600^{* *}$ & $\mathbf{0 . 8 7 5}$ & & & & \\
3. Flexibility & 4.800 & 1.190 & $0.416^{* *}$ & $0.549^{* *}$ & $\mathbf{0 . 8 1 6}$ & & & \\
4. Cost & 4.471 & 1.266 & $0.375^{* *}$ & $0.506^{* *}$ & $0.356^{* *}$ & $\mathbf{0 . 8 2 8}$ & & \\
5. Organizational performance & 4.347 & 1.330 & $0.307^{* *}$ & $0.396^{* *}$ & $0.443^{* *}$ & $0.490^{* *}$ & $\mathbf{0 . 8 8 6}$ & \\
6. Entrepreneurial orientation & 4.443 & 1.233 & $0.425^{* *}$ & $0.415^{* *}$ & $0.500^{* *}$ & $0.434^{* *}$ & $0.482^{* *}$ & $\mathbf{0 . 7 4 2}$ \\
\hline
\end{tabular}

The data of the diagonal is the square root of AVE (in bold)

** Sign. at the 0.01 level 
Table 3: EFA for manufacturing capability, organizational performance and entrepreneurial orientation

\begin{tabular}{|c|c|c|c|c|c|c|}
\hline Construct & F1 & F2 & F3 & F4 & F5 & F6 \\
\hline \multicolumn{7}{|l|}{ Quality } \\
\hline $\begin{array}{l}\text { Produce high performance products that meet } \\
\text { customer needs }\end{array}$ & 0.741 & & & & & \\
\hline Produce consistent quality products with low defects & 0.765 & & & & & \\
\hline $\begin{array}{l}\text { Offer highly reliable products that meet customer } \\
\text { needs }\end{array}$ & 0.845 & & & & & \\
\hline $\begin{array}{l}\text { Produce high quality products that meet our customer } \\
\text { needs }\end{array}$ & 0.788 & & & & & \\
\hline \multicolumn{7}{|l|}{ Delivery } \\
\hline Correct quantity with the right kind of products & & 0.766 & & & & \\
\hline Deliver products quickly or short lead-time & & 0.797 & & & & \\
\hline Provide on-time delivery to our customers & & 0.835 & & & & \\
\hline Provide reliable delivery to our customers & & 0.807 & & & & \\
\hline Reduce customer order taking time & & 0.616 & & & & \\
\hline \multicolumn{7}{|l|}{ Flexibility } \\
\hline Rapidly change production volume & & & 0.525 & & & \\
\hline Produce customized product features & & & 0.699 & & & \\
\hline $\begin{array}{l}\text { Produce broad product specifications within same } \\
\text { facility }\end{array}$ & & & 0.839 & & & \\
\hline Make rapid product mix changes & & & 0.718 & & & \\
\hline \multicolumn{7}{|l|}{ Cost } \\
\hline Produce products with low costs & & & & 0.755 & & \\
\hline Produce products with low inventory costs & & & & 0.719 & & \\
\hline Produce products with low overhead costs & & & & 0.812 & & \\
\hline Offer price as low or lower than our competitors & & & & 0.688 & & \\
\hline \multicolumn{7}{|l|}{ Organizational performance } \\
\hline Growth in sales & & & & & 0.723 & \\
\hline Return on sales (ROS) & & & & & 0.843 & \\
\hline Growth in return on sales (ROS) & & & & & 0.857 & \\
\hline Growth in profit & & & & & 0.878 & \\
\hline Growth in market share & & & & & 0.761 & \\
\hline Return on investment (ROI) & & & & & 0.866 & \\
\hline Growth in ROI & & & & & 0.884 & \\
\hline Return on assets (ROA) & & & & & 0.874 & \\
\hline Growth in ROA & & & & & 0.867 & \\
\hline \multicolumn{7}{|l|}{ Entrepreneurial orientation } \\
\hline $\begin{array}{l}\text { Our company favours a strong emphasis on R\&D, } \\
\text { technological leadership, and innovations }\end{array}$ & & & & & & 0.639 \\
\hline $\begin{array}{l}\text { Very many new lines of products/services were } \\
\text { marketed in the past } 3 \text { years }\end{array}$ & & & & & & 0.680 \\
\hline $\begin{array}{l}\text { Changes in product or service lines have usually been } \\
\text { quite dramatic }\end{array}$ & & & & & & 0.696 \\
\hline $\begin{array}{l}\text { Typically we initiate actions to which competitors } \\
\text { then respond }\end{array}$ & & & & & & 0.704 \\
\hline $\begin{array}{l}\text { We are very often the first business to introduce new } \\
\text { products, administrative techniques, processing } \\
\text { technologies, etc. }\end{array}$ & & & & & & 0.818 \\
\hline $\begin{array}{l}\text { Our company has a strong tendency to be ahead of } \\
\text { others in introducing novel ideas or products }\end{array}$ & & & & & & 0.724 \\
\hline $\begin{array}{l}\text { Typically we adopt a bold, aggressive posture in order } \\
\text { to maximize the probability of exploiting potential } \\
\text { opportunities }\end{array}$ & & & & & & 0.401 \\
\hline Eigen value & 13.933 & 4.116 & 2.501 & 2.031 & 1.624 & 1.240 \\
\hline$\%$ of variance & 42.221 & 12.472 & 7.759 & 6.155 & 4.920 & 3.757 \\
\hline Cumulative explained variance (\%) & 42.221 & 54.692 & 59.873 & 55.157 & 69.355 & 72.345 \\
\hline
\end{tabular}


Table 4: CFA for manufacturing capability, organizational performance and entrepreneurial orientation

\begin{tabular}{|c|c|c|c|}
\hline Construct & $\begin{array}{c}\text { Cronbach's } \\
\alpha\end{array}$ & $\begin{array}{c}\text { Standardized } \\
\text { loading }\end{array}$ & t-value \\
\hline \multicolumn{4}{|l|}{ Quality $(A V E=0.765)$} \\
\hline Produce high performance products that meet customer needs & 0.933 & 0.86 & 19.29 \\
\hline Produce consistent quality products with low defects & & 0.89 & 20.42 \\
\hline Offer highly reliable products that meet customer needs & & 0.92 & 21.59 \\
\hline Produce high quality products that meet our customer needs & & 0.86 & 19.40 \\
\hline \multicolumn{4}{|l|}{ Delivery $(A V E=0.766)$} \\
\hline Correct quantity with the right kind of products & 0.940 & 0.85 & 19.22 \\
\hline Deliver products quickly or short lead-time & & 0.90 & 20.82 \\
\hline Provide on-time delivery to our customers & & 0.90 & 20.78 \\
\hline Provide reliable delivery to our customers & & 0.93 & 22.00 \\
\hline Reduce customer order taking time & & 0.79 & 17.13 \\
\hline \multicolumn{4}{|l|}{ Flexibility $(A V E=0.667)$} \\
\hline Rapidly change production volume & 0.886 & 0.72 & 14.59 \\
\hline Produce customized product features & & 0.83 & 17.93 \\
\hline Produce broad product specifications within same facility & & 0.85 & 18.66 \\
\hline Make rapid product mix changes & & 0.86 & 18.79 \\
\hline \multicolumn{4}{|l|}{$\operatorname{Cost}(A V E=0.687)$} \\
\hline Produce products with low costs & 0.900 & 0.83 & 18.03 \\
\hline Produce products with low inventory costs & & 0.85 & 18.53 \\
\hline Produce products with low overhead costs & & 0.88 & 19.62 \\
\hline Offer price as low or lower than our competitors & & 0.78 & 19.46 \\
\hline \multicolumn{4}{|l|}{ Organizational performance $(A V E=0.786)$} \\
\hline Growth in sales & 0.971 & 0.78 & 16.74 \\
\hline Return on sales (ROS) & & 0.85 & 19.32 \\
\hline Growth in return on sales (ROS) & & 0.88 & 20.43 \\
\hline Growth in profit & & 0.90 & 21.11 \\
\hline Growth in market share & & 0.82 & 18.14 \\
\hline Return on investment (ROI) & & 0.93 & 22.35 \\
\hline Growth in ROI & & 0.95 & 23.34 \\
\hline Return on assets (ROA) & & 0.93 & 22.44 \\
\hline Growth in ROA & & 0.94 & 22.78 \\
\hline \multicolumn{4}{|l|}{ Entrepreneurial orientation $(A V E=0.551)$} \\
\hline $\begin{array}{l}\text { Our company favours a strong emphasis on R\&D, technological leadership, } \\
\text { and innovations }\end{array}$ & 0.892 & 0.72 & 14.58 \\
\hline Very many new lines of products/services were marketed in the past 3 years & & 0.72 & 14.60 \\
\hline Changes in product or service lines have usually been quite dramatic & & 0.74 & 15.38 \\
\hline Typically we initiate actions to which competitors then respond & & 0.82 & 17.83 \\
\hline $\begin{array}{l}\text { We are very often the first business to introduce new products, administrative } \\
\text { techniques, processing technologies, etc. }\end{array}$ & & 0.86 & 19.15 \\
\hline $\begin{array}{l}\text { Our company has a strong tendency to be ahead of others in introducing novel } \\
\text { ideas or products }\end{array}$ & & 0.78 & 16.56 \\
\hline $\begin{array}{l}\text { Typically we adopt a bold, aggressive posture in order to maximize the } \\
\text { probability of exploiting potential opportunities }\end{array}$ & & 0.50 & 9.43 \\
\hline
\end{tabular}


Table 5: OLS analyses: Predictors of organizational performance

\begin{tabular}{|c|c|c|c|c|}
\hline \multirow[t]{2}{*}{ Variables } & \multicolumn{4}{|c|}{ Standardised Coefficients } \\
\hline & Step 1 & Step 2 & Step 3 & \multirow[t]{2}{*}{ Outcome } \\
\hline Control variable & & & & \\
\hline Industry size & 0.050 & -0.012 & -0.024 & \\
\hline \multicolumn{5}{|c|}{ Independent variables: } \\
\hline Quality & & 0.005 & -0.017 & H1a: not supported \\
\hline Delivery & & 0.024 & -0.008 & H1b: not supported \\
\hline Flexibility & & $0.207 * *$ & $0.218 * *$ & H1c: supported \\
\hline Cost & & $0.278 * *$ & $0.284 * *$ & H1d: supported \\
\hline EO (moderator) & & $0.245 * *$ & $0.255 * *$ & \\
\hline \multicolumn{5}{|c|}{ Interaction terms: } \\
\hline Quality*EO & & & -0.113 & H2a: not supported \\
\hline Delivery $*$ EO & & & -0.050 & H2b: not supported \\
\hline Flexibility * EO & & & $0.153 *$ & H2c: supported \\
\hline Cost $* \mathrm{EO}$ & & & $0.127 *$ & H2d: supported \\
\hline $\mathrm{R}^{2}$ & 0.003 & 0.354 & 0.381 & \\
\hline$\Delta \mathrm{R}^{2}$ & - & 0.352 & 0.027 & \\
\hline Adjusted $\mathrm{R}^{2}$ & -001 & 0.342 & 0.361 & \\
\hline $\mathrm{F}$ & 0.829 & 29.457 & 19.570 & \\
\hline$\Delta \mathrm{F}$ & - & $35.096 * *$ & $3.414 * *$ & \\
\hline
\end{tabular}

*Sign. at the 0.05 level

** Sign. at the 0.01 level 
Figure 1: Research model

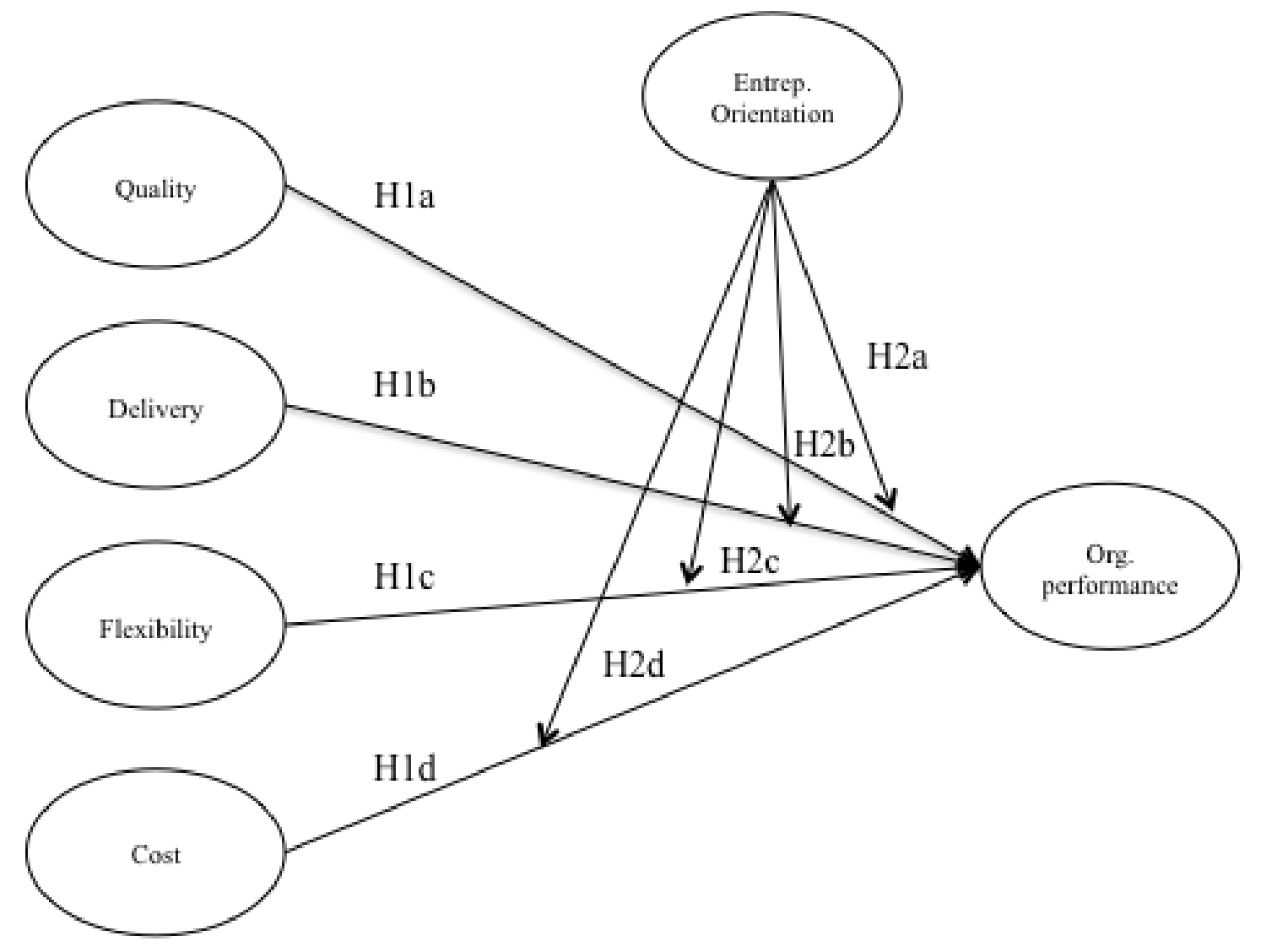


Figure 2: Flexibility and organizational performance under low/high EO

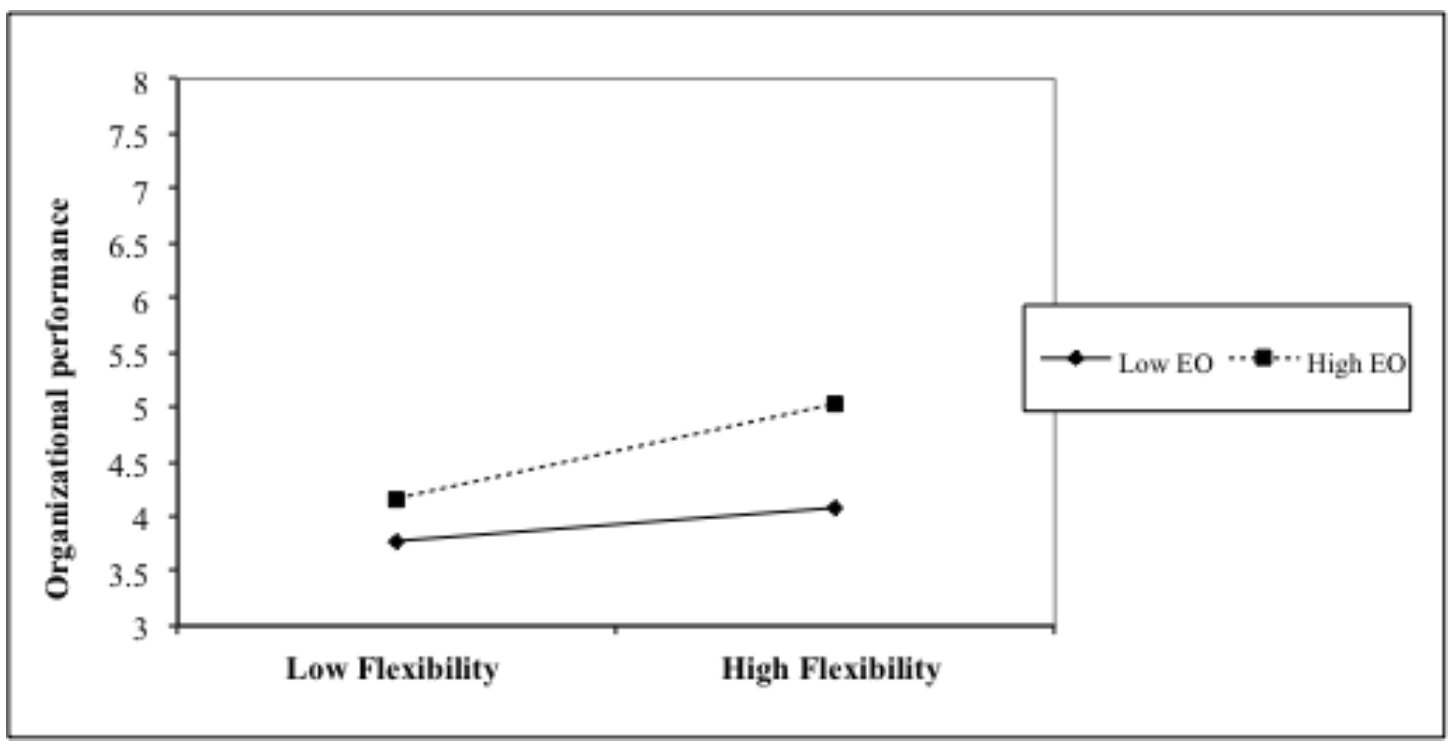

Figure 3: Cost and organizational performance under low/high EO

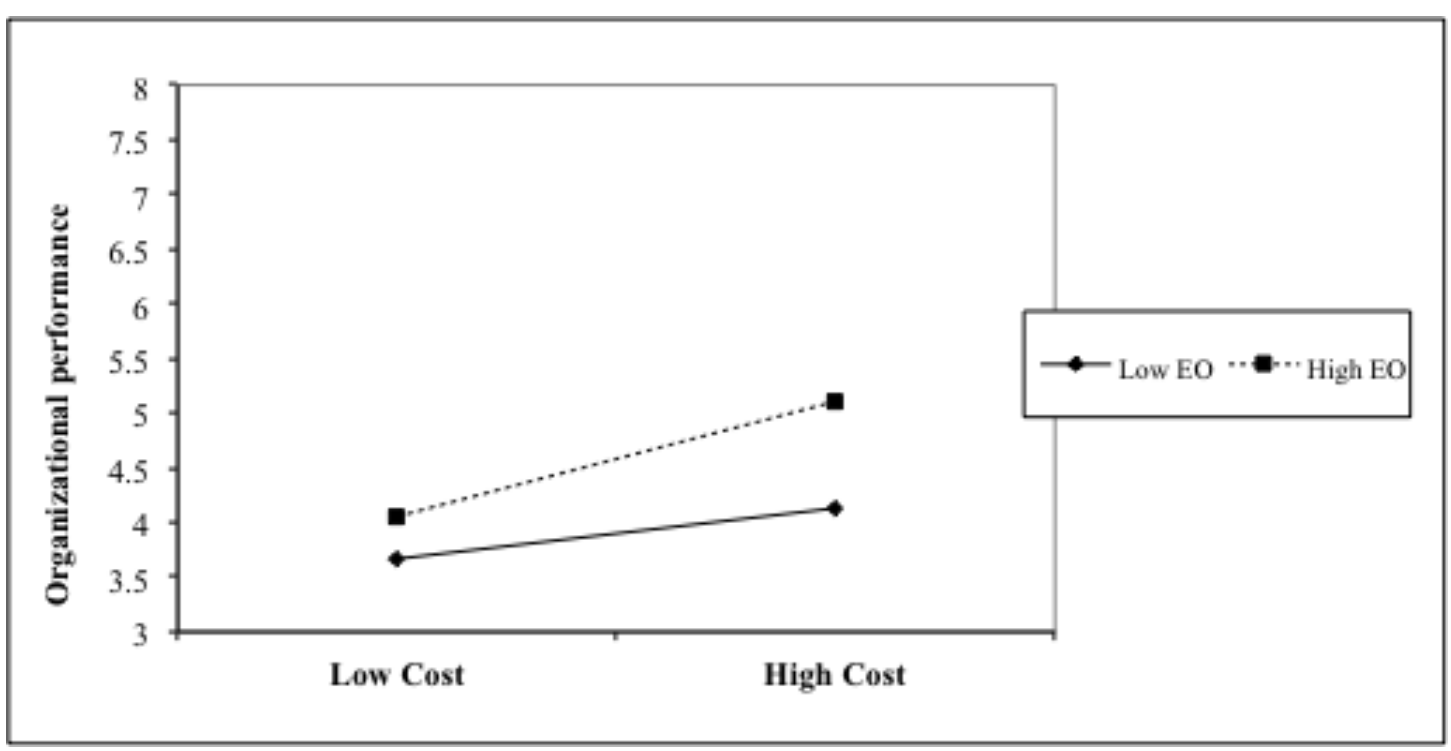

